\title{
Lewis Base Activation of Lewis Acids. Catalytic Enantioselective Addition of Silyl Enol Ethers of Achiral Methyl Ketones to Aldehydes.
}

\author{
Scott E. Denmark* and John R. Heemstra Jr. \\ Roger Adams Laboratory, Department of Chemistry, University of Illinois \\ Urbana, Illinois 61801
}

SUPPORTING INFORMATION

\section{General Experimental}

All reactions were performed in oven-dried $\left(140^{\circ} \mathrm{C}\right)$ or flame dried glassware under an atmosphere of dry $\mathrm{N}_{2}$. The following reaction solvents were distilled from the indicated drying agents: dichloromethane $\left(\mathrm{P}_{2} \mathrm{O}_{5}\right)$ and tetrahydrofuran (Na/benzophenone). The solvents for recrystallization were: benzene (Fisher ACS grade), and hexanes (Fisher ACS grade). The solvents for chromatography and filtration were: diethylether (Mallinckrodt), pentane (Fisher ACS grade), and dichloromethane $\left(\mathrm{CaCl}_{2}\right)$. Column chromatography was performed using EM Science 230-400-mesh silica gel. Benzaldehyde, 1-naphthaldehyde, 4-anisaldehyde, 4trifluoromethylbenzaldehyde, (E)-cinnamaldehyde, (E)-2-methylcinnamaldehyde, furfural, 2thiophenecarboxaldehyde and hydrocinnamaldehyde were freshly distilled before use. 2Naphthaldehyde (Aldrich) was sublimed prior to use. Silicon tetrachloride (Gelest) was heated at reflux for $24 \mathrm{~h}$ and then distilled prior to use unless otherwise noted. Chlolrotrimethylsilane (TMSCl, Aldrich) was distilled from $\mathrm{CaH}_{2}$ prior to use. Acetophenone, 2-hexanone, 4-methyl-2pentanone, 3-methyl-2-butanone, and 3,3-dimethyl-2-butanone (Aldrich) were distilled and stored over $3 \AA$ molecular sieves. Diisopropylamine and diisopropylethylamine were freshly distilled from $\mathrm{CaH}_{2}$ prior to use. Tetrabutylammonium iodide and tetrabutylammonium triflate were recrystallized from toluene and dried under vacuum prior to use. All reaction temperatures 
correspond to internal temperatures measured be Teflon-coated thermocouples unless otherwise noted.

${ }^{1} \mathrm{H}$ NMR, ${ }^{13} \mathrm{C}$ NMR ${ }^{19} \mathrm{~F}$ NMR spectra were recorded on Varian Unity $400\left(400 \mathrm{MHz},{ }^{1} \mathrm{H}\right.$; $\left.100 \mathrm{MHz},{ }^{13} \mathrm{C} ; 376 \mathrm{MHz},{ }^{19} \mathrm{~F}\right)$ and Unity $500\left(500 \mathrm{MHz},{ }^{1} \mathrm{H} ; 126 \mathrm{MHZ},{ }^{13} \mathrm{C}\right)$ spectrometers. Spectra were referenced to residual chloroform $\left(7.26 \mathrm{ppm},{ }^{1} \mathrm{H}, 77.23 \mathrm{ppm},{ }^{13} \mathrm{C}\right),{ }^{19} \mathrm{~F}$ spectra was referenced internally to $\mathrm{C}_{6} \mathrm{~F}_{6}$. Chemical shifts are reported in ppm, multiplicities are indicated by s (singlet), d (doublet), t (triplet), q (quartet), p (pentet), h (hextet), m (multiplet) and br (broad). Coupling Constants, J, are reported in Hertz. Mass Spectrometry was performed by the University of Illinois Mass Spectrometer Center. EI mass spectra were performed on a 70-VSE spectrometer. CI mass spectra were performed on a 70-VSE-B spectrometer. Data are reported in the form of $(\mathrm{m} / \mathrm{z})$. Infared spectra (IR) were recorded on a Mattson Galaxy 5020 spectrophotometer in $\mathrm{NaCl}$ cells. Peaks are recorded in $\mathrm{cm}^{-1}$ with indicated relative intensities: $\mathrm{s}$ (strong, 67-100\%); m (medium, 34-66\%); and w (weak, 0-33\%). Elemental analyses were performed by the University of Illinois Microanalytical Service Laboratory. Melting points (mp) were determined on a Thomas-Hoover capillary melting point apparatus in sealed tubes and are corrected. Kugelrohr distillations were performed on a Büchi GKR-50 Kugelrohr and temperatures are air bath temperatures. Analytical thin-layer chromatography was performed on Merck silica gel plates with QF-254 indicator. Visualization was accomplished with UV(254) and 4-anisaldehyde.

Optical rotation data was obtained on a JASCO DIP-360 digital polarimeter and are reported as follows: $(\mathrm{c}=\mathrm{g} / 100 \mathrm{~mL})$, and solvent. Analytical supercritical fluid chromatography (SFC) was performed on a Berger Instruments packed-column SFC with built-in photometric detector (220 nm) using Daicel Chiralpak AD, AS, OD, OJ, and Welko columns.

\section{Literature Preparations}

The preparation of 2-trimethylsilyloxy-1-hexene (2), 4-methyl-2-trimethylsilyloxy-1pentene (3) 3-methyl-2-trimethylsilyloxy-1-butene (4) 2-phenyl-2-trimethylsilyloxy-1-ethene, 
and (6) followed the procedure described by Enders et. al. ${ }^{1}$ Preparation of 2-trimethylsilyloxy-1propene (1) and 3,3-dimethyl-2-trimethylsilyloxy-1-butene (5) and followed the procedure described by Myles and Bigham. ${ }^{2}$ The preparation of $(R, R)-N, N$ '-bis[4,5-dihydro-3,5-dimethyl4-(3H-dinaphtho[2,1-d:1',2'-f][1,3,2]-2-oxo-diazaphosphephepino)]-N,N'-dimethyl-1,5pentanediamine $(R, R)-7$ followed the procedure described by Denmark and Wynn. ${ }^{3}$ 


\section{$\underline{\text { Initial Studies }}$}

\section{Reaction between 2 and Benzaldehyde (9) [JRH-I-27]}

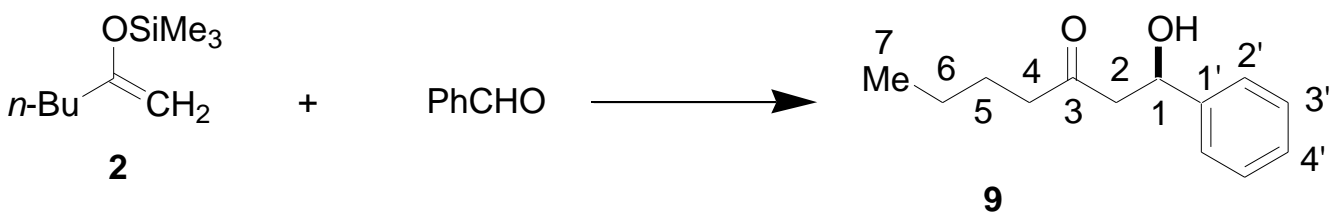

Benzaldehyde (102 $\mu \mathrm{L}, 1.0 \mathrm{mmol})$ was added to a flame-dried, 5-mL, 2-neck flask under $\mathrm{N}_{2}$ containing a solution of $42 \mathrm{mg}(0.05 \mathrm{mmol}, 0.05$ equiv) of bisphosphoramide $(R, R)-7$ in $\mathrm{CH}_{2} \mathrm{Cl}_{2}(2 \mathrm{~mL})$. To this solution was added $126 \mu \mathrm{L}\left(1.1 \mathrm{mmol}, 1.1\right.$ equiv) of $\mathrm{SiCl}_{4}$ in one portion, and the reaction mixture was cooled to $-78{ }^{\circ} \mathrm{C}$ (bath temperature) over $15 \mathrm{~min}$. Then, $206 \mathrm{mg}$ (1.2 mmol, 1.2 equiv) of 2 was added dropwise neat over $5 \mathrm{~min}$. The resulting mixture was stirred at $-78{ }^{\circ} \mathrm{C}$ for $2 \mathrm{~h}$ whereupon the cold reaction mixture was poured into a rapidly stirring solution of $1 / 11.0 \mathrm{M} \mathrm{KH}_{2} \mathrm{PO}_{4} /$ sat. aq. $\mathrm{KF}(25 \mathrm{~mL})$ at $0^{\circ} \mathrm{C}$. This biphasic mixture was stirred vigorously for $8 \mathrm{~h}$ after which the aqueous layer was washed with $\mathrm{CH}_{2} \mathrm{Cl}_{2}(3 \mathrm{x} 50 \mathrm{~mL})$. The combined organic extracts were dried over $\mathrm{Na}_{2} \mathrm{SO}_{4}$, filtered and the filtrate was concentrated in vacuo. The residue was purified by column chromatography (silica gel, pentane/Et $2 \mathrm{O}, 4 / 1$ ). The product-containing fractions were combined and the solvent was removed in vacuo to yield $83 \mathrm{mg}(81 \%)$ of 9 as a clear, colorless oil. ${ }^{4}$

\section{Data for 9:}

${ }^{1}$ H NMR: $\quad\left(500 \mathrm{MHz}, \mathrm{CHCl}_{3}\right)$

7.36-7.26 (m, $5 \mathrm{H}, \mathrm{H}(\operatorname{aryl})), 5.16(\mathrm{dt}, J=8.8,3.5,1 \mathrm{H}, \mathrm{HC}(1)), 3.43(\mathrm{~d}, J=3.3,1$ $\mathrm{H}, \mathrm{OH}), 2.88\left(\underline{\mathrm{ABX}}, J_{\mathrm{AB}}=17.3, J_{\mathrm{AX}}=9.4,1 \mathrm{H}, \mathrm{H}_{a} \mathrm{C}(2)\right), 2.81\left(\mathrm{AB} \underline{\mathrm{B}}, J_{\mathrm{AB}}=17.3\right.$, $\left.J_{\mathrm{BX}}=2.8,1 \mathrm{H}, \mathrm{H}_{b} \mathrm{C}(2)\right), 2.43\left(\mathrm{t}, J=7.3,2 \mathrm{H}, \mathrm{H}_{2} \mathrm{C}(4)\right), 1.57$ (quint, $J=7.3,2 \mathrm{H}$, $\left.\mathrm{H}_{2} \mathrm{C}(5)\right), 1.30$ (sext, $\left.J=7.3,2 \mathrm{H}, \mathrm{H}_{2} \mathrm{C}(6)\right), 0.90$ (t, $J=7.3,3 \mathrm{H}, \mathrm{H}_{3} \mathrm{C}(7)$ )

SFC: $\quad(R)-9 t_{\mathrm{R}} 4.08 \min (99.0 \%) ;(S)-9 t_{\mathrm{R}} 3.32 \min (1.0 \%)$ (AD column, 125 bar, 3.0 $\mathrm{mL} / \mathrm{min}, 7.0 \% \mathrm{MeOH})$ 


\section{Reaction between 3 and Benzaldehyde (10) [JRH-I-36]}

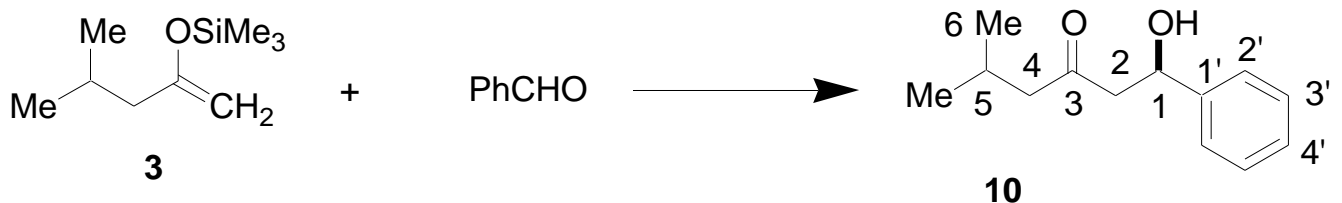

Benzaldehyde $(51 \mu \mathrm{L}, 0.5 \mathrm{mmol})$ was added to a flame-dried, 5-mL, 2-neck flask under $\mathrm{N}_{2}$ containing a solution of $21 \mathrm{mg}(0.025 \mathrm{mmol}, 0.05$ equiv $)$ of bisphosphoramide $(R, R)-7$ in $\mathrm{CH}_{2} \mathrm{Cl}_{2}(1 \mathrm{~mL})$. To this solution was added $63 \mu \mathrm{L}\left(0.55 \mathrm{mmol}, 1.1\right.$ equiv) of $\mathrm{SiCl}_{4}$ in one portion, and the reaction mixture was cooled to $-78{ }^{\circ} \mathrm{C}$ (bath temperature) over $15 \mathrm{~min}$. Then, $103 \mathrm{mg}$ ( $0.6 \mathrm{mmol}, 1.2$ equiv) of 3 was added dropwise neat over $5 \mathrm{~min}$. The resulting mixture was stirred at $-78{ }^{\circ} \mathrm{C}$ for $2 \mathrm{~h}$ whereupon the cold reaction mixture was poured into a rapidly stirring solution of $1 / 11.0 \mathrm{M} \mathrm{KH}_{2} \mathrm{PO}_{4} /$ sat. aq. $\mathrm{KF}(25 \mathrm{~mL})$ at $0^{\circ} \mathrm{C}$. This biphasic mixture was stirred vigorously for $8 \mathrm{~h}$ after which the aqueous layer was washed with $\mathrm{CH}_{2} \mathrm{Cl}_{2}(3 \mathrm{x} 50 \mathrm{~mL})$. The combined organic extracts were dried over $\mathrm{Na}_{2} \mathrm{SO}_{4}$, filtered and the filtrate was concentrated in vacuo. The residue was purified by column chromatography (silica gel, pentane/Et $2 \mathrm{O}, 4 / 1$ ). The product-containing fractions were combined and the solvent was removed in vacuo to yield $72 \mathrm{mg}(70 \%)$ of $\mathbf{1 0}$ as a clear, colorless oil. ${ }^{4}$

\section{Data for 10:}

${ }^{1} \mathrm{H}$ NMR: $\quad\left(500 \mathrm{MHz}, \mathrm{CHCl}_{3}\right)$

7.36-7.27 (m, $5 \mathrm{H}, \mathrm{H}(\operatorname{aryl})), 5.16(\mathrm{dt}, J=9.0,3.4,1 \mathrm{H}, \mathrm{HC}(1)), 3.41$ (d, $J=3.3,1$ $\mathrm{H}, \mathrm{OH}), 2.85\left(\underline{\mathrm{ABX}}, J_{\mathrm{AB}}=17.5, J_{\mathrm{AX}}=9.5,1 \mathrm{H}, \mathrm{H}_{a} \mathrm{C}(2)\right), 2.78\left(\mathrm{~A} \underline{\mathrm{BX}}, J_{\mathrm{AB}}=17.5\right.$, $\left.J_{\mathrm{BX}}=2.8,1 \mathrm{H}, \mathrm{H}_{b} \mathrm{C}(2)\right), 2.34\left(\mathrm{~d}, J=7.0,2 \mathrm{H}, \mathrm{H}_{2} \mathrm{C}(4)\right), 2.14$ (septet, $J=6.7,1 \mathrm{H}$, $\left.\mathrm{H}_{2} \mathrm{C}(5)\right), 0.96\left(\mathrm{~d}, J=6.7,6 \mathrm{H}, 2 \times \mathrm{H}_{3} \mathrm{C}(6)\right)$

SFC: $\quad(R)-10 t_{\mathrm{R}} 2.57 \min (99.0 \%) ;(S)-\mathbf{1 0} t_{\mathrm{R}} 3.16 \min (1.0 \%)$ (AD column, 125 bar, 3.0 $\mathrm{mL} / \mathrm{min}, 7.0 \% \mathrm{MeOH})$ 
Reaction between 4 and Benzaldehyde (11) [JRH-I-31]

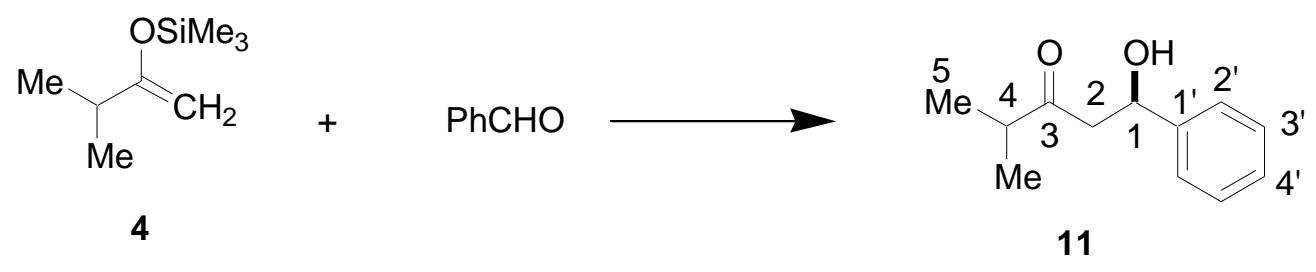

Benzaldehyde $(51 \mu \mathrm{L}, 0.5 \mathrm{mmol})$ was added to a flame-dried, 5-mL, 2-neck flask under $\mathrm{N}_{2}$ containing a solution of $21 \mathrm{mg}(0.025 \mathrm{mmol}, 0.05$ equiv $)$ of bisphosphoramide $(R, R)-7$ in $\mathrm{CH}_{2} \mathrm{Cl}_{2}(1 \mathrm{~mL})$. To this solution was added $63 \mu \mathrm{L}\left(0.55 \mathrm{mmol}, 1.1\right.$ equiv) of $\mathrm{SiCl}_{4}$ in one portion, and the reaction mixture was cooled to $-78^{\circ} \mathrm{C}$ (bath temperature) over 15 min. Then, $118 \mu \mathrm{L}$ (95 mg, $0.6 \mathrm{mmol}, 1.2$ equiv) of 4 was added dropwise over $5 \mathrm{~min}$. The resulting mixture was stirred at $-78{ }^{\circ} \mathrm{C}$ for $2 \mathrm{~h}$ whereupon the cold reaction mixture was poured into a rapidly stirring solution of $1 / 11.0 \mathrm{M} \mathrm{KH}_{2} \mathrm{PO}_{4} /$ sat. aq. $\mathrm{KF}(25 \mathrm{~mL})$ at $0^{\circ} \mathrm{C}$. This biphasic mixture was stirred vigorously for $8 \mathrm{~h}$ after which the aqueous layer was washed with $\mathrm{CH}_{2} \mathrm{Cl}_{2}$ ( 3 x $50 \mathrm{~mL}$ ). The combined organic extracts were dried over $\mathrm{Na}_{2} \mathrm{SO}_{4}$, filtered and the filtrate was concentrated in vacuo. The residue was purified by column chromatography (silica gel, pentane/ $\left.\mathrm{Et}_{2} \mathrm{O}, 4 / 1\right)$. The product-containing fractions were combined and the solvent was removed in vacuo to yield $69 \mathrm{mg}(72 \%)$ of $\mathbf{1 1}$ as a clear, colorless oil. ${ }^{4}$

\section{$\underline{\text { Data for 11: }}$}

${ }^{1} \mathrm{H}$ NMR: $\quad\left(500 \mathrm{MHz}, \mathrm{CHCl}_{3}\right)$

7.38-7.25 (m, $5 \mathrm{H}, \mathrm{H}(\operatorname{aryl})), 5.15$ (dt, $J=8.3,3.3,1 \mathrm{H}, \mathrm{HC}(1)), 3.44$ (d, $J=3.2,1$ H, OH), 2.87 (m, $2 \mathrm{H}, \mathrm{HC}(2)), 2.59$ (sept, $\left.J=7.1,1 \mathrm{H}, \mathrm{H}_{2} \mathrm{C}(4)\right), 1.11(\mathrm{~d}, J=6.8$, $\left.6 \mathrm{H}, 2 \times \mathrm{H}_{3} \mathrm{C}(5)\right)$

SFC: $\quad(R)-11 t_{\mathrm{R}} 2.46 \min (99.5 \%) ;(S)-11 t_{\mathrm{R}} 2.71 \min (1.5 \%)$ (AD column, 125 bar, 3.0 $\mathrm{mL} / \mathrm{min}, 7.0 \% \mathrm{MeOH})$ 


\section{Reaction between 6 and Benzaldehyde (12) [JRH-I-34]}

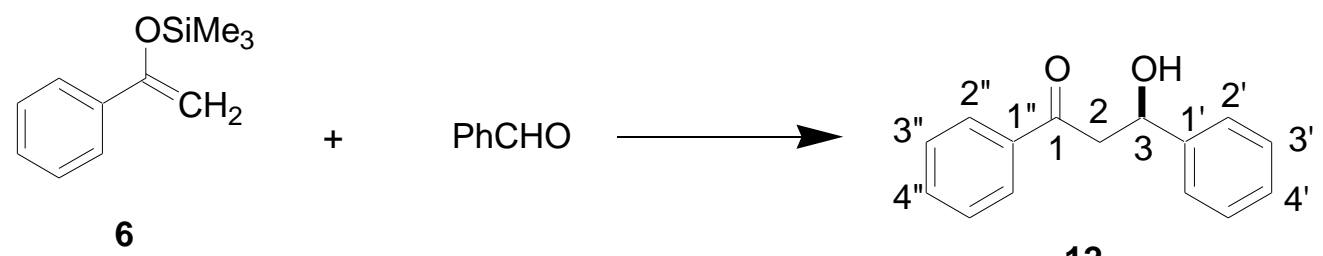

12

Benzaldehyde (51 $\mu \mathrm{L}, 0.5 \mathrm{mmol}$ ) was added to a flame-dried, 5-mL, 2-neck flask under $\mathrm{N}_{2}$ containing a solution of $21 \mathrm{mg}(0.025 \mathrm{mmol}, 0.05$ equiv) of bisphosphoramide $(R, R)-7$ in $\mathrm{CH}_{2} \mathrm{Cl}_{2}(1 \mathrm{~mL})$. To this solution was added $63 \mu \mathrm{L}\left(0.55 \mathrm{mmol}, 1.1\right.$ equiv) of $\mathrm{SiCl}_{4}$ in one portion, and the reaction mixture was cooled to $-78{ }^{\circ} \mathrm{C}$ (bath temperature) over $15 \mathrm{~min}$. Then, $102 \mu \mathrm{L}$ (115 mg, $0.6 \mathrm{mmol}, 1.2$ equiv) of 6 was added dropwise over 5 min. The resulting mixture was to stirred at $-78{ }^{\circ} \mathrm{C}$ for $2 \mathrm{~h}$ whereupon the cold reaction mixture was poured into a rapidly stirring solution of $1 / 11.0 \mathrm{M} \mathrm{KH}_{2} \mathrm{PO}_{4} /$ sat. aq. $\mathrm{KF}(25 \mathrm{~mL})$ at $0^{\circ} \mathrm{C}$. This biphasic mixture was stirred vigorously for $8 \mathrm{~h}$ after which the aqueous layer was washed with $\mathrm{CH}_{2} \mathrm{Cl}_{2}(3$ x $50 \mathrm{~mL}$ ). The combined organic extracts were dried over $\mathrm{Na}_{2} \mathrm{SO}_{4}$, filtered and the filtrate was concentrated in vacuo. The residue was purified by column chromatography (silica gel, pentane/Et $\left.{ }_{2} \mathrm{O}, 4 / 1\right)$. The product-containing fractions were combined and the solvent was removed in vacuo to yield $73 \mathrm{mg}(76 \%)$ of $\mathbf{1 2}$ as a clear, colorless oil. ${ }^{4}$

Data for 12:

${ }^{1}$ H NMR: $\quad\left(500 \mathrm{MHz}, \mathrm{CHCl}_{3}\right)$ 7.96 (d, $J=8.3,2 \mathrm{H}, 2$ x HC(2”)), 7.59 (t, $J=7.3,1 \mathrm{H}, \mathrm{HC}(4 ")), 7.48-7.44$ (m, 4 $\mathrm{H}, 2$ x $\left.\left.\mathrm{HC}\left(3^{\prime \prime \prime}\right)\right)+2 \times \mathrm{HC}\left(2^{\prime}\right)\right), 7.39\left(\mathrm{t}, J=7.8,2 \mathrm{H}, 2 \times \mathrm{HC}\left(3^{\prime}\right)\right), 7.31(\mathrm{t}, J=7.1$, $\left.1 \mathrm{H}, \mathrm{HC}\left(4^{\prime}\right)\right), 5.35$ (dt, $\left.J=6.1,2.9,1 \mathrm{H}, \mathrm{HC}(1)\right), 3.62(\mathrm{~d}, J=3.2,1 \mathrm{H}, \mathrm{OH}), 3.39$ $\left(\mathrm{d}, J=6.6,1 \mathrm{H}, \mathrm{H}_{2} \mathrm{C}(2)\right)$

SFC: $\quad(R)-12 t_{\mathrm{R}} 6.53 \mathrm{~min}(97.0 \%) ;(S)-\mathbf{1 2} t_{\mathrm{R}} 6.82 \mathrm{~min}(3.0 \%)$ (AD column, $225 \mathrm{bar}, 3.0$ $\mathrm{mL} / \mathrm{min}, 6.0 \% \mathrm{MeOH}$ ) 


\section{$\underline{\mathrm{SiCl}}_{4}$ Loading Study}

\section{Reaction of 2 and Benzaldehyde with 1.5 equiv of $\mathrm{SiCl}_{4}(9) \quad$ [JRH-I-47]}

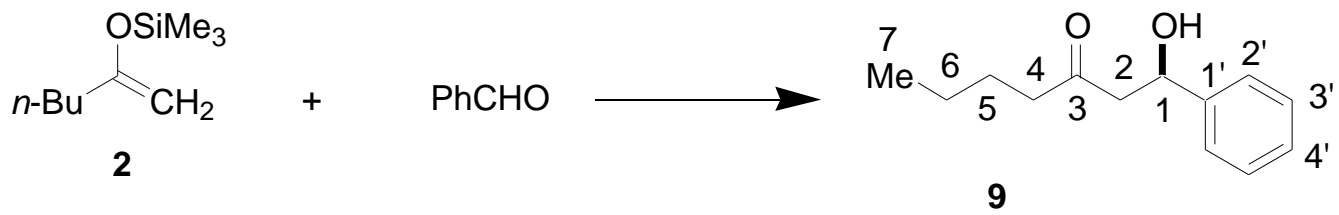

Benzaldehyde (51 $\mu \mathrm{L}, 0.5 \mathrm{mmol}$ ) was added to a flame-dried, $5 \mathrm{~mL}$, 2-neck flask under $\mathrm{N}_{2}$ containing a solution of $21 \mathrm{mg}(0.025 \mathrm{mmol}, 0.05$ equiv) of bisphosphoramide $(R, R)-7$ in $\mathrm{CH}_{2} \mathrm{Cl}_{2}(1 \mathrm{~mL})$. To this solution was added $86 \mu \mathrm{L}$ (0.75 mmol, 1.5 equiv) of $\mathrm{SiCl}_{4}$ in one portion, and the reaction mixture was cooled to $-78{ }^{\circ} \mathrm{C}$ (bath temperature) over $15 \mathrm{~min}$. Then, $103 \mathrm{mg}$ ( $0.6 \mathrm{mmol}, 1.2$ equiv) of 2 was added dropwise neat over $5 \mathrm{~min}$. The resulting mixture was stirred at $-78{ }^{\circ} \mathrm{C}$ for $2.5 \mathrm{~h}$ whereupon the cold reaction mixture was poured into a rapidly stirring solution of $1 / 11.0 \mathrm{M} \mathrm{KH}_{2} \mathrm{PO}_{4}$ / sat. aq. $\mathrm{KF}(25 \mathrm{~mL})$ at $0^{\circ} \mathrm{C}$. This biphasic mixture was stirred vigorously for $8 \mathrm{~h}$ after which the aqueous layer was washed with $\mathrm{CH}_{2} \mathrm{Cl}_{2}(3 \times 50 \mathrm{~mL})$. The combined organic extracts were dried over $\mathrm{Na}_{2} \mathrm{SO}_{4}$, filtered and the filtrate was concentrated in vacuo. The residue was purified by column chromatography (silica gel, pentane/Et ${ }_{2} \mathrm{O}, 4 / 1$ ). The product-containing fractions were combined and the solvent was removed in vacuo to yield $89 \mathrm{mg}(86 \%)$ of 9 as a clear, colorless oil. ${ }^{4}$

\section{Data for 9:}

${ }^{1} \mathrm{H}$ NMR: $\quad\left(500 \mathrm{MHz}, \mathrm{CHCl}_{3}\right)$

7.37-7.26 (m, $5 \mathrm{H}, \mathrm{H}(\operatorname{aryl})$ ), 5.16 (dt, $J=8.7,3.4,1 \mathrm{H}, \mathrm{HC}(1)), 3.43$ (d, $J=3.2,1$ $\mathrm{H}, \mathrm{OH}), 2.88\left(\underline{\mathrm{ABX}}, J_{\mathrm{AB}}=17.3, J_{\mathrm{AX}}=9.1,1 \mathrm{H}, \mathrm{H}_{a} \mathrm{C}(2)\right), 2.81\left(\mathrm{ABX}, J_{\mathrm{AB}}=17.3\right.$, $\left.J_{\mathrm{BX}}=3.1,1 \mathrm{H}, \mathrm{H}_{b} \mathrm{C}(2)\right), 2.45$ (t, $J=7.3,2 \mathrm{H}, \mathrm{H}_{2} \mathrm{C}(4)$ ), 1.58 (quint, $J=7.3,2 \mathrm{H}$, $\left.\mathrm{H}_{2} \mathrm{C}(5)\right), 1.30$ (sext, $\left.J=7.3,2 \mathrm{H}, \mathrm{H}_{2} \mathrm{C}(6)\right), 0.90$ (t, $J=7.3,3 \mathrm{H}, \mathrm{H}_{3} \mathrm{C}(7)$ )

SFC: $\quad(R)-9 \quad t_{\mathrm{R}} 3.24 \min (99.5 \%)$; $(S)-9 t_{\mathrm{R}} 3.47 \min (0.5 \%)$ (AD column, 125 bar, 3.0 $\mathrm{mL} / \mathrm{min}, 7.0 \% \mathrm{MeOH}$ ) 


\section{Reaction of 2 and Benzaldehyde with 2.0 equiv of $\mathrm{SiCl}_{4}(9) \quad$ [JRH-I-44]}

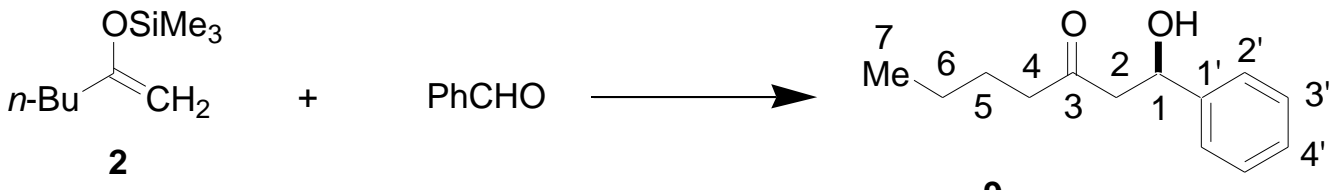

Benzaldehyde (51 $\mathrm{L}, 0.5 \mathrm{mmol})$ was added to a flame-dried, 5-mL, 2-neck flask under $\mathrm{N}_{2}$ containing a solution of $21 \mathrm{mg}(0.025 \mathrm{mmol}, 0.05$ equiv) of bisphosphoramide $(R, R)-7$ in $\mathrm{CH}_{2} \mathrm{Cl}_{2}(1 \mathrm{~mL})$. To this solution was added $115 \mu \mathrm{L}$ (1.0 mmol, 2.0 equiv) of $\mathrm{SiCl}_{4}$ in one portion, and the reaction mixture was cooled to $-78{ }^{\circ} \mathrm{C}$ (bath temperature) over $15 \mathrm{~min}$. Then, $103 \mathrm{mg}$ ( $0.6 \mathrm{mmol}, 1.2$ equiv) of 2 was added dropwise over $5 \mathrm{~min}$. The resulting mixture was stirred at $-78{ }^{\circ} \mathrm{C}$ for $2.5 \mathrm{~h}$ whereupon the cold reaction mixture was poured into a rapidly stirring solution of 1/1 $1.0 \mathrm{M} \mathrm{KH}_{2} \mathrm{PO}_{4}$ / sat. aq. $\mathrm{KF}(25 \mathrm{~mL})$ at $0^{\circ} \mathrm{C}$. This biphasic mixture was stirred vigorously for $8 \mathrm{~h}$ after which the aqueous layer was washed with $\mathrm{CH}_{2} \mathrm{Cl}_{2}(3 \times 50 \mathrm{~mL})$. The combined organic extracts were dried over $\mathrm{Na}_{2} \mathrm{SO}_{4}$, filtered and the filtrate was concentrated in vacuo. The residue was purified by column chromatography (silica gel, pentane/ $\mathrm{Et}_{2} \mathrm{O}, 4 / 1$ ). The product-containing fractions were combined and the solvent was removed in vacuo to yield 83 $\mathrm{mg}(81 \%)$ of $\mathbf{9}$ as a clear, colorless oil. ${ }^{7 \mathrm{~b}}$

Data for 9:

${ }^{1}$ H NMR: $\quad\left(500 \mathrm{MHz}, \mathrm{CHCl}_{3}\right)$

7.38-7.26 (m, $5 \mathrm{H}, \mathrm{H}(\operatorname{aryl})$ ), 5.15 (dd, $J=8.9,3.4,1 \mathrm{H}, \mathrm{HC}(1)), 3.43$ (d, $J=3.1,1$ $\mathrm{H}, \mathrm{OH}), 2.86\left(\underline{\mathrm{ABX}}, J_{\mathrm{AB}}=17.3, J_{\mathrm{AX}}=9.4,1 \mathrm{H}, \mathrm{H}_{a} \mathrm{C}(2)\right), 2.80\left(\mathrm{~A} \underline{\mathrm{B} X}, J_{\mathrm{AB}}=17.3\right.$, $\left.J_{\mathrm{BX}}=2.8,1 \mathrm{H}, \mathrm{H}_{b} \mathrm{C}(2)\right), 2.42\left(\mathrm{t}, J=7.332 \mathrm{H}, \mathrm{H}_{2} \mathrm{C}(4)\right.$ ), 1.58 (quint, $J=7.2,2 \mathrm{H}$, $\mathrm{H}_{2} \mathrm{C}(5)$ ), 1.31 (sext, $\left.J=7.3,2 \mathrm{H}, \mathrm{H}_{2} \mathrm{C}(6)\right), 0.93$ (t, $J=7.3,3 \mathrm{H}, \mathrm{H}_{3} \mathrm{C}(7)$ )

SFC: $\quad(R)-9$ t $t_{\mathrm{R}} 2.98 \min (99.5 \%)$; $(S)-9 t_{\mathrm{R}} 3.22 \min (0.5 \%)$ (AD column, 125 bar, 3.0 $\mathrm{mL} / \mathrm{min}, 7.0 \% \mathrm{MeOH})$ 


\section{Reaction of 2 and Benzaldehyde with 3.0 equiv of $\mathrm{SiCl}_{4}(9) \quad$ [JRH-I-46]}

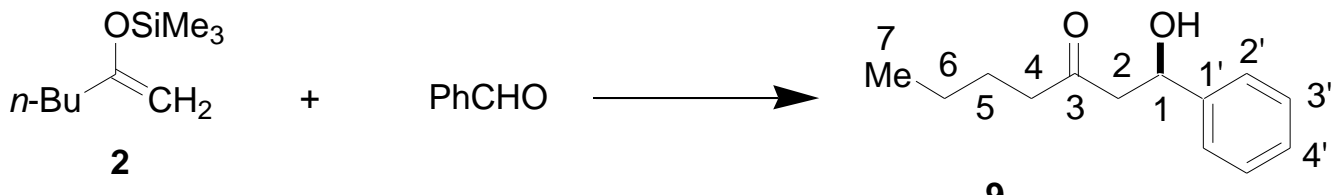

Benzaldehyde (51 $\mathrm{L}, 0.5 \mathrm{mmol}$ ) was added to a flame-dried, 5-mL, 2-neck flask under $\mathrm{N}_{2}$ containing a solution of $21 \mathrm{mg}(0.025 \mathrm{mmol}, 0.05$ equiv) of bisphosphoramide $(R, R)-7$ in $\mathrm{CH}_{2} \mathrm{Cl}_{2}(1 \mathrm{~mL})$. To this solution was added $172 \mu \mathrm{L}$ (1.5 mmol, 3.0 equiv) of $\mathrm{SiCl}_{4}$ in one portion, and the reaction mixture was cooled to $-78{ }^{\circ} \mathrm{C}$ (bath temperature) over $15 \mathrm{~min}$. Then, $103 \mathrm{mg}$ ( $0.6 \mathrm{mmol}, 1.2$ equiv) of 2 was added dropwise neat over $5 \mathrm{~min}$. The resulting mixture was stirred at $-78^{\circ} \mathrm{C}$ for $2.5 \mathrm{~h}$ whereupon the cold reaction mixture was poured into a rapidly stirring solution of 1/1 $1.0 \mathrm{M} \mathrm{KH}_{2} \mathrm{PO}_{4}$ / sat. aq. $\mathrm{KF}(25 \mathrm{~mL})$ at $0^{\circ} \mathrm{C}$. This biphasic mixture was stirred vigorously for $8 \mathrm{~h}$ after which the aqueous layer was washed with $\mathrm{CH}_{2} \mathrm{Cl}_{2}(3 \times 50 \mathrm{~mL})$. The combined organic extracts were dried over $\mathrm{Na}_{2} \mathrm{SO}_{4}$, filtered and the filtrate was concentrated in vacuo. The residue was purified by column chromatography (silica gel, pentane/ $\mathrm{Et}_{2} \mathrm{O}, 4 / 1$ ). The product-containing fractions were combined and the solvent was removed in vacuo to yield $83 \mathrm{mg}(81 \%)$ of 9 as a clear, colorless oil. ${ }^{4}$

\section{Data for 9:}

${ }^{1}$ H NMR: $\quad\left(500 \mathrm{MHz}, \mathrm{CHCl}_{3}\right)$

7.37-7.26 (m, $5 \mathrm{H}, \mathrm{H}(\operatorname{aryl})), 5.15$ (dt, $J=8.5,3.1,1 \mathrm{H}, \mathrm{HC}(1)), 3.38$ (d, $J=2.9,1$ $\mathrm{H}, \mathrm{OH}), 2.85\left(\underline{\mathrm{ABX}}, J_{\mathrm{AB}}=17.3, J_{\mathrm{AX}}=9.2,1 \mathrm{H}, \mathrm{H}_{a} \mathrm{C}(2)\right), 2.79\left(\mathrm{~A} \underline{\mathrm{B} X}, J_{\mathrm{AB}}=17.3\right.$, $\left.J_{\mathrm{BX}}=2.7,1 \mathrm{H}, \mathrm{H}_{b} \mathrm{C}(2)\right), 2.42\left(\mathrm{t}, J=7.3,2 \mathrm{H}, \mathrm{H}_{2} \mathrm{C}(4)\right), 1.54$ (quint, $J=7.3,2 \mathrm{H}$, $\left.\mathrm{H}_{2} \mathrm{C}(5)\right), 1.30$ (sext, $\left.J=7.3,2 \mathrm{H}, \mathrm{H}_{2} \mathrm{C}(6)\right), 0.91$ (t, $J=7.32,3 \mathrm{H}, \mathrm{H}_{3} \mathrm{C}(7)$ )

SFC: $\quad(R)-9$ t $t_{\mathrm{R}} 3.18 \mathrm{~min}(99.5 \%)$; $(S)-9 t_{\mathrm{R}} 3.38 \mathrm{~min}(0.5 \%)$ (AD column, $125 \mathrm{bar}, 3.0$ $\mathrm{mL} / \mathrm{min}, 7.0 \% \mathrm{MeOH}$ ) 
Reaction of 2 and Benzaldehyde with 4.0 equiv of $\mathrm{SiCl}_{4}(9) \quad$ [JRH-I-45]

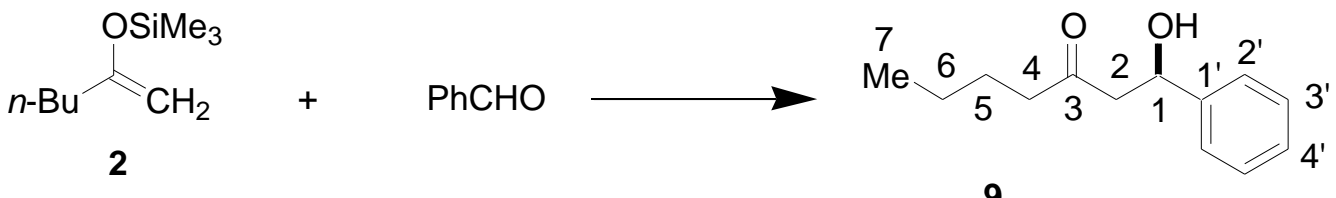

Benzaldehyde (51 $\mathrm{L}, 0.5 \mathrm{mmol}$ ) was added to a flame-dried, 5-mL, 2-neck flask under $\mathrm{N}_{2}$ containing a solution of $21 \mathrm{mg}(0.025 \mathrm{mmol}, 0.05$ equiv) of bisphosphoramide $(R, R)-7$ in $\mathrm{CH}_{2} \mathrm{Cl}_{2}(1 \mathrm{~mL})$. To this solution was added $86 \mu \mathrm{L}$ (2.0 mmol, 4.0 equiv) of $\mathrm{SiCl}_{4}$ in one portion, and the reaction mixture was cooled to $-78{ }^{\circ} \mathrm{C}$ (bath temperature) over $15 \mathrm{~min}$. Then, $103 \mathrm{mg}$ ( $0.6 \mathrm{mmol}, 1.2$ equiv) of $\mathbf{2}$ was added dropwise over $5 \mathrm{~min}$. The resulting mixture was stirred at $-78{ }^{\circ} \mathrm{C}$ for $2.5 \mathrm{~h}$ whereupon the cold reaction mixture was poured into a rapidly stirring solution of $1 / 11.0 \mathrm{M} \mathrm{KH}_{2} \mathrm{PO}_{4}$ / sat. aq. $\mathrm{KF}(25 \mathrm{~mL})$ at $0^{\circ} \mathrm{C}$. This biphasic mixture was stirred vigorously for $8 \mathrm{~h}$ after which the aqueous layer was washed with $\mathrm{CH}_{2} \mathrm{Cl}_{2}(3 \times 50 \mathrm{~mL})$. The combined organic extracts were dried over $\mathrm{Na}_{2} \mathrm{SO}_{4}$, filtered and the filtrate was concentrated in vacuo. The residue was purified by column chromatography (silica gel, pentane/Et $\mathrm{t}_{2} \mathrm{O}, 4 / 1$ ). The productcontaining fractions were combined and the solvent was removed in vacuo to yield $84 \mathrm{mg}(82 \%)$ of $\mathbf{9}$ as a clear, colorless oil. ${ }^{4}$

\section{Data for 9:}

${ }^{1}$ H NMR: $\quad\left(500 \mathrm{MHz}, \mathrm{CHCl}_{3}\right)$

7.38-7.25 (m, $5 \mathrm{H}, \mathrm{H}(\operatorname{aryl})), 5.15$ (dt, $J=8.8,3.3,1 \mathrm{H}, \mathrm{HC}(1)), 3.38$ (d, $J=3.2,1$ $\mathrm{H}, \mathrm{OH}), 2.87\left(\underline{\mathrm{ABX}}, J_{\mathrm{AB}}=17.3, J_{\mathrm{AX}}=9.6,1 \mathrm{H}, \mathrm{H}_{a} \mathrm{C}(2)\right), 2.80\left(\mathrm{~A} \underline{\mathrm{B} X}, J_{\mathrm{AB}}=17.3\right.$, $\left.J_{\mathrm{BX}}=2.7,1 \mathrm{H}, \mathrm{H}_{b} \mathrm{C}(2)\right), 2.42\left(\mathrm{t}, J=7.3,2 \mathrm{H}, \mathrm{H}_{2} \mathrm{C}(4)\right), 1.56$ (quint, $J=7.3,2 \mathrm{H}$, $\left.\mathrm{H}_{2} \mathrm{C}(5)\right), 1.32$ (sext, $\left.J=7.4,2 \mathrm{H}, \mathrm{H}_{2} \mathrm{C}(6)\right), 0.92$ (t, $J=7.3,3 \mathrm{H}, \mathrm{H}_{3} \mathrm{C}(7)$ )

SFC: $\quad(R)-9 t_{\mathrm{R}} 2.99 \min (99.5 \%)$; $(S)-9 t_{\mathrm{R}} 3.22 \min (0.5 \%)$ (AD column, $125 \mathrm{bar}, 3.0$ $\mathrm{mL} / \mathrm{min}, 7.0 \% \mathrm{MeOH}$ ) 


\section{Study of TBAOTf as an additive}

\section{Reaction of 1 and Benzaldehyde with 0.05 equiv of TBAOTf (8) [JRH-II-12]}

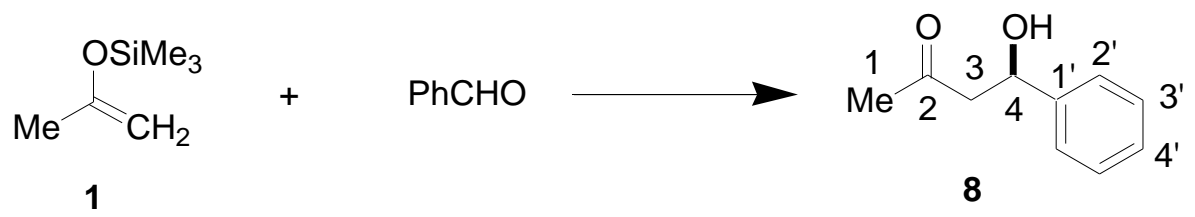

Benzaldehyde $(102 \mu \mathrm{L}, 1.0 \mathrm{mmol})$ was added to a flame-dried, 5-mL, 2-neck flask under $\mathrm{N}_{2}$ containing a solution of $42 \mathrm{mg}(0.05 \mathrm{mmol}, 0.05$ equiv) of bisphosphoramide $(R, R)-7$ and 20 mg of tetrabutylammonium triflate $\left(0.05 \mathrm{mmol}, 0.05\right.$ equiv) in $\mathrm{CH}_{2} \mathrm{Cl}_{2}(2 \mathrm{~mL})$. To this solution was added $172 \mu \mathrm{L}\left(1.5 \mathrm{mmol}, 1.5\right.$ equiv) of $\mathrm{SiCl}_{4}$ in one portion and the reaction mixture was cooled to $-78^{\circ} \mathrm{C}$ (bath temperature) over $15 \mathrm{~min}$. Then, $198 \mu \mathrm{L}$ (156 mg, $1.2 \mathrm{mmol}, 1.2 \mathrm{equiv}$ ) of 1 was added dropwise over 5 min. The resulting mixture was stirred at $-78{ }^{\circ} \mathrm{C}$ for $2 \mathrm{~h}$, whereupon $3 \mathrm{~mL}$ of chilled $\mathrm{CH}_{2} \mathrm{Cl}_{2}$ was added before the cold reaction mixture was poured into a rapidly stirring solution of $1 / 1$ sat. aq. $\mathrm{NaHCO}_{3} / \mathrm{sat}$. aq. $\mathrm{KF}(25 \mathrm{~mL})$ at $0^{\circ} \mathrm{C}$. This biphasic mixture was stirred vigorously for $8 \mathrm{~h}$ after which the aqueous layer was washed with $\mathrm{CH}_{2} \mathrm{Cl}_{2}(3$ x $50 \mathrm{~mL}$ ). The combined organic extracts were dried over $\mathrm{Na}_{2} \mathrm{SO}_{4}$, filtered and the filtrate was concentrated in vacuo. The residue was purified by column chromatography (silica gel, pentane/ $\left./ \mathrm{Et}_{2} \mathrm{O}, 1 / 1\right)$. The product-containing fractions were combined and the solvent was removed in vacuo to yield $118 \mathrm{mg}(72 \%)$ of $\mathbf{8}$ as a clear, colorless oil. ${ }^{4}$

\section{Data for 8:}

${ }^{1}$ H NMR: $\quad\left(500 \mathrm{MHz}, \mathrm{CHCl}_{3}\right)$

7.37-7.26 (m, $5 \mathrm{H}, \mathrm{H}(\operatorname{aryl})), 5.16(\mathrm{dt}, J=9.3,3.2,1 \mathrm{H}, \mathrm{HC}(4)), 3.7$ (d, $J=2.93,1$ $\mathrm{H}, \mathrm{OH}), 2.89\left(\underline{\mathrm{ABX}}, J_{\mathrm{AB}}=17.8, J_{\mathrm{AX}}=9.6,1 \mathrm{H} \mathrm{H}_{a} \mathrm{C}(3)\right), 2.83\left(\mathrm{ABX}, J_{\mathrm{AB}}=17.8\right.$, $\left.\mathrm{J}_{\mathrm{BX}}=2.91 \mathrm{H}, \mathrm{H}_{b} \mathrm{C}(4)\right), 2.20\left(\mathrm{~s}, 3 \mathrm{H} \mathrm{H}_{3} \mathrm{C}(1)\right)$

SFC: $\quad(R)-8 t_{\mathrm{R}} 3.16 \min (98.0 \%) ;(S)-8 t_{\mathrm{R}} 3.47 \min (2.0 \%)$ (AS column, 125 bar, 2.5 $\mathrm{mL} / \mathrm{min}, 5.0 \% \mathrm{MeOH})$ 


\section{Reaction of 2 and Benzaldehyde with 0.05 equiv of TBAOTf (9) [JRH-I-92]}

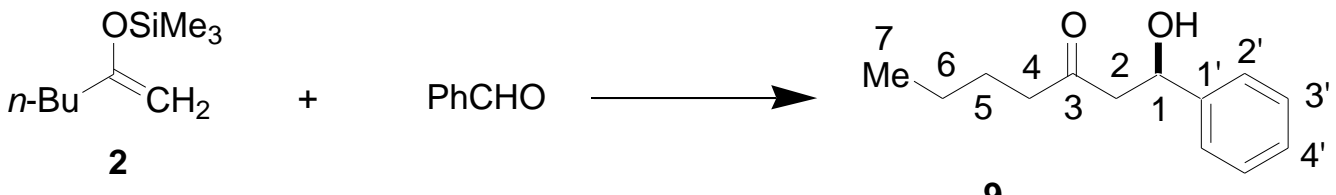

Benzaldehyde (102 $\mu \mathrm{L}, 1.0 \mathrm{mmol})$ was added to a flame-dried, 5-mL, 2-neck flask under $\mathrm{N}_{2}$ containing a solution of $42 \mathrm{mg}(0.05 \mathrm{mmol}, 0.05$ equiv) of bisphosphoramide $(R, R)-7$ and 20 $\mathrm{mg}$ of tetrabutylammonium triflate $\left(0.05 \mathrm{mmol}, 0.05\right.$ equiv) in $\mathrm{CH}_{2} \mathrm{Cl}_{2}(2 \mathrm{~mL})$. To this solution was added $172 \mu \mathrm{L}$ ( $1.5 \mathrm{mmol}, 1.5$ equiv) of $\mathrm{SiCl}_{4}$ in one portion and the reaction mixture was cooled to $-78{ }^{\circ} \mathrm{C}$ (bath temperature) over $15 \mathrm{~min}$. Then, $206 \mathrm{mg}$ (1.2 mmol, 1.2 equiv) of 2 was added dropwise neat over $5 \mathrm{~min}$. The resulting mixture was stirred at $-78{ }^{\circ} \mathrm{C}$ for $2 \mathrm{~h}$, whereupon $3 \mathrm{~mL}$ of chilled $\mathrm{CH}_{2} \mathrm{Cl}_{2}$ was added before the cold reaction mixture was poured into a rapidly stirring solution of $1 / 1$ sat. aq. $\mathrm{NaHCO}_{3} / \mathrm{sat}$. aq. $\mathrm{KF}(25 \mathrm{~mL})$ at $0^{\circ} \mathrm{C}$. This biphasic mixture was stirred vigorously for $8 \mathrm{~h}$ after which the aqueous layer was washed with $\mathrm{CH}_{2} \mathrm{Cl}_{2}(3 \times 50 \mathrm{~mL})$. The combined organic extracts were dried over $\mathrm{Na}_{2} \mathrm{SO}_{4}$, filtered and the filtrate was concentrated in vасио. The residue was purified by column chromatography (silica gel, pentane/Et ${ }_{2} \mathrm{O}, 4 / 1$ ). The product-containing fractions were combined and the solvent was removed in vacuo to yield $196 \mathrm{mg}(95 \%)$ of 9 as a clear, colorless oil. ${ }^{4}$

Data for 9:

${ }^{1}$ H NMR: $\quad\left(500 \mathrm{MHz}, \mathrm{CHCl}_{3}\right)$

7.37-7.26 (m, $5 \mathrm{H}, \mathrm{H}(\operatorname{aryl})), 5.16$ (dd, $J=9.0,3.4,1 \mathrm{H}, \mathrm{HC}(1)), 3.45$ (br s, $1 \mathrm{H}$, $\mathrm{OH}), 2.89\left(\underline{\mathrm{ABX}}, J_{\mathrm{AB}}=17.3, J_{\mathrm{AX}}=9.7,1 \mathrm{H}, \mathrm{H}_{a} \mathrm{C}(2)\right), 2.80\left(\mathrm{ABX}, J_{\mathrm{AB}}=17.3, J_{\mathrm{BX}}\right.$ $=2.8,1 \mathrm{H}, \mathrm{H}_{b} \mathrm{C}(2)$ ), 2.43 (t, $J=7.3,2 \mathrm{H}, \mathrm{H}_{2} \mathrm{C}(4)$ ), 1.57 (quint, $J=7.3,2 \mathrm{H}$, $\left.\mathrm{H}_{2} \mathrm{C}(5)\right), 1.31$ (sext, $\left.J=7.3,2 \mathrm{H}, \mathrm{H}_{2} \mathrm{C}(6)\right), 0.90$ (t, $J=7.3,3 \mathrm{H}, \mathrm{H}_{3} \mathrm{C}(7)$ )

SFC: $\quad(R)-9$ t $t_{\mathrm{R}} 3.74 \min (99.5 \%) ;(S)-9 t_{\mathrm{R}} 4.07 \min (0.5 \%)$ (AD column, $125 \mathrm{bar}, 3.0$ $\mathrm{mL} / \mathrm{min}, 6.0 \% \mathrm{MeOH}$ ) 


\section{Reaction of 3 and Benzaldehyde with 0.05 equiv of TBAOTf (10) [JRH-I-95]}

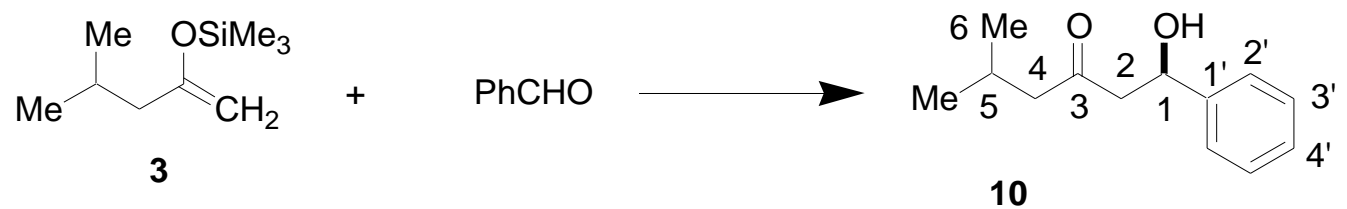

Benzaldehyde (102 $\mu \mathrm{L}, 1.0 \mathrm{mmol})$ was added to a flame-dried, 5-mL, 2-neck flask under $\mathrm{N}_{2}$ containing a solution of $42 \mathrm{mg}(0.05 \mathrm{mmol}, 0.05$ equiv) of bisphosphoramide $(R, R)-7$ and 20 $\mathrm{mg}$ of tetrabutylammonium triflate $\left(0.05 \mathrm{mmol}, 0.05\right.$ equiv) in $\mathrm{CH}_{2} \mathrm{Cl}_{2}(2 \mathrm{~mL})$. To this solution was added $172 \mu \mathrm{L}$ ( $1.5 \mathrm{mmol}, 1.5$ equiv) of $\mathrm{SiCl}_{4}$ in one portion and the reaction mixture was cooled to $-78{ }^{\circ} \mathrm{C}$ (bath temperature) over $15 \mathrm{~min}$. Then, $206 \mathrm{mg}$ (1.2 mmol, 1.2 equiv) of $\mathbf{3}$ was added dropwise over $5 \mathrm{~min}$. The resulting mixture was stirred at $-78{ }^{\circ} \mathrm{C}$ for $2 \mathrm{~h}$, whereupon 3 $\mathrm{mL}$ of chilled $\mathrm{CH}_{2} \mathrm{Cl}_{2}$ was added before the cold reaction mixture was poured into a rapidly stirring solution of $1 / 1$ sat. aq. $\mathrm{NaHCO}_{3} / \mathrm{sat}$. aq. $\mathrm{KF}(25 \mathrm{~mL})$ at $0^{\circ} \mathrm{C}$. This biphasic mixture was stirred vigorously for $8 \mathrm{~h}$ after which the aqueous layer was washed with $\mathrm{CH}_{2} \mathrm{Cl}_{2}(3 \times 50 \mathrm{~mL})$. The combined organic extracts were dried over $\mathrm{Na}_{2} \mathrm{SO}_{4}$, filtered and the filtrate was concentrated in vacuo. The residue was purified by column chromatography (silica gel, pentane/ $\mathrm{Et}_{2} \mathrm{O}, 4 / 1$ ). The product-containing fractions were combined and the solvent was removed in vacuo to yield $175 \mathrm{mg}(85 \%)$ of $\mathbf{1 0}$ as a clear, colorless oil. ${ }^{4}$

\section{Data for 10:}

${ }^{1}$ H NMR: $\quad\left(500 \mathrm{MHz}, \mathrm{CHCl}_{3}\right)$

7.37-7.27 (m, $5 \mathrm{H}, \mathrm{H}(\operatorname{aryl})$ ), 5.16 (dd, $J=9.0,3.4,1 \mathrm{H}, \mathrm{HC}(1)), 3.37$ (br s, $1 \mathrm{H}$, $\mathrm{OH}), 2.83\left(\underline{\mathrm{ABX}}, J_{\mathrm{AB}}=17.6, J_{\mathrm{AX}}=9.7,1 \mathrm{H}, \mathrm{H}_{a} \mathrm{C}(2)\right), 2.78\left(\mathrm{ABX}, J_{\mathrm{AB}}=17.6\right.$, $\left.J_{\mathrm{BX}}=2.7,1 \mathrm{H}, \mathrm{H}_{b} \mathrm{C}(2)\right), 2.31\left(\mathrm{~d}, J=7.1,2 \mathrm{H}, \mathrm{H}_{2} \mathrm{C}(4)\right), 2.15$ (septet, $J=6.7,1 \mathrm{H}$, $\left.\mathrm{H}_{2} \mathrm{C}(5)\right), 0.92\left(\mathrm{~d}, J=6.6,6 \mathrm{H}, 2 \times \mathrm{H}_{3} \mathrm{C}(6)\right)$

SFC: $\quad(R)-\mathbf{1 0} t_{\mathrm{R}} 2.81 \mathrm{~min}(99.0 \%) ;(S)-\mathbf{1 0} t_{\mathrm{R}} 3.16 \min (1.0 \%)$ (AD column, $125 \mathrm{bar}, 3.0$ $\mathrm{mL} / \mathrm{min}, 7.0 \% \mathrm{MeOH}$ ) 


\section{Reaction of 4 and Benzaldehyde with 0.05 equiv of TBAOTf (11) [JRH-I-93]}

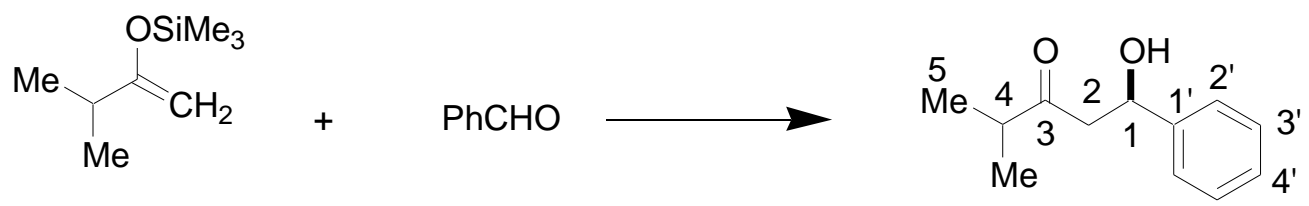

4

11

Benzaldehyde (102 $\mu \mathrm{L}, 1.0 \mathrm{mmol})$ was added to a flame-dried, 5-mL, 2-neck flask under $\mathrm{N}_{2}$ containing a solution of $42 \mathrm{mg}(0.05 \mathrm{mmol}, 0.05$ equiv) of bisphosphoramide $(R, R)-7$ and 20 $\mathrm{mg}$ of tetrabutylammonium triflate $\left(0.05 \mathrm{mmol}, 0.05\right.$ equiv) in $\mathrm{CH}_{2} \mathrm{Cl}_{2}(2 \mathrm{~mL})$. To this solution was added $172 \mu \mathrm{L}\left(1.5 \mathrm{mmol}, 1.5\right.$ equiv) of $\mathrm{SiCl}_{4}$ in one portion and the reaction mixture was cooled to $-78^{\circ} \mathrm{C}$ (bath temperature) over $15 \mathrm{~min}$. Then, $118 \mu \mathrm{L}$ (95 mg, $0.6 \mathrm{mmol}, 1.2$ equiv) of 4 was added dropwise over 5 min. The resulting mixture was stirred at $-78{ }^{\circ} \mathrm{C}$ for $2 \mathrm{~h}$, whereupon $3 \mathrm{~mL}$ of chilled $\mathrm{CH}_{2} \mathrm{Cl}_{2}$ was added before the cold reaction mixture was poured into a rapidly stirring solution of $1 / 1$ sat. aq. $\mathrm{NaHCO}_{3} / \mathrm{sat}$. aq. $\mathrm{KF}(25 \mathrm{~mL})$ at $0^{\circ} \mathrm{C}$. This biphasic mixture was stirred vigorously for $8 \mathrm{~h}$ after which the aqueous layer was washed with $\mathrm{CH}_{2} \mathrm{Cl}_{2}$ (3 x $50 \mathrm{~mL}$ ). The combined organic extracts were dried over $\mathrm{Na}_{2} \mathrm{SO}_{4}$, filtered and the filtrate was concentrated in vacuo. The residue was purified by column chromatography (silica gel, pentane/Et $2 \mathrm{O}, 4 / 1)$. The product-containing fractions were combined and the solvent was removed in vacuo to yield $146 \mathrm{mg}$ (76\%) of $\mathbf{1 1}$ as a clear, colorless oil. ${ }^{4}$

\section{Data for 11:}

${ }^{1}$ H NMR: $\quad\left(500 \mathrm{MHz}, \mathrm{CHCl}_{3}\right)$

7.38-7.26 (m, $5 \mathrm{H}, \mathrm{H}(\operatorname{aryl})), 5.11(\mathrm{dd}, J=8.3,3.9,1 \mathrm{H}, \mathrm{HC}(1)), 3.42(\mathrm{br} \mathrm{s}, 1 \mathrm{H}$, $\mathrm{OH}), 2.88(\mathrm{~m}, 2 \mathrm{H}, \mathrm{HC}(2)), 2.59$ (sept, $\left.J=6.8,1 \mathrm{H}, \mathrm{H}_{2} \mathrm{C}(4)\right), 1.10$ (d, $J=6.8,6 \mathrm{H}$, $\left.2 \times \mathrm{H}_{3} \mathrm{C}(5)\right)$

SFC: $\quad(R)-11 t_{\mathrm{R}} 2.62 \mathrm{~min}(99.5 \%) ;(S)-\mathbf{1 1} t_{\mathrm{R}} 2.902 \mathrm{~min}(0.5 \%)$ (AD column, $125 \mathrm{bar}, 3.0$ $\mathrm{mL} / \mathrm{min}, 7.0 \% \mathrm{MeOH}$ ) 


\section{Reaction of 6 and Benzaldehyde with 0.05 equiv of TBAOTf (12) [JRH-I-94]}

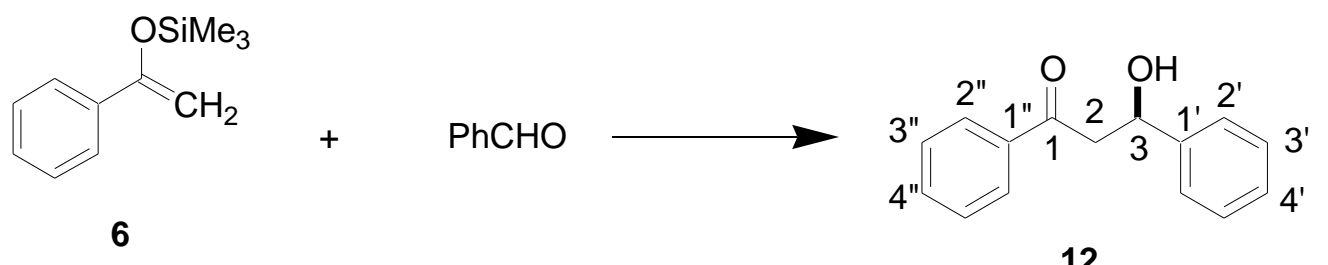

12

Benzaldehyde (102 $\mu \mathrm{L}, 1.0 \mathrm{mmol}$ ) was added to a flame-dried, 5-mL, 2-neck flask under $\mathrm{N}_{2}$ containing a solution of $42 \mathrm{mg}(0.05 \mathrm{mmol}, 0.05$ equiv) of bisphosphoramide $(R, R)-7$ and 20 $\mathrm{mg}$ of tetrabutylammonium triflate $\left(0.05 \mathrm{mmol}, 0.05\right.$ equiv) in $\mathrm{CH}_{2} \mathrm{Cl}_{2}(2 \mathrm{~mL})$. To this solution was added $172 \mu \mathrm{L}$ ( $1.5 \mathrm{mmol}, 1.5$ equiv) of $\mathrm{SiCl}_{4}$ in one portion and the reaction mixture was cooled to $-78{ }^{\circ} \mathrm{C}$ (bath temperature) over $15 \mathrm{~min}$. Then, $248 \mu \mathrm{L}$ (231 $\mathrm{mg}, 1.2 \mathrm{mmol}, 1.2$ equiv) of 6 was added dropwise over $5 \mathrm{~min}$. The resulting mixture was stirred at $-78{ }^{\circ} \mathrm{C}$ for $2 \mathrm{~h}$, whereupon the cold reaction mixture was poured into a rapidly stirring solution of $1 / 11.0 \mathrm{M}$ $\mathrm{KH}_{2} \mathrm{PO}_{4} / \mathrm{sat}$. aq. $\mathrm{KF}(25 \mathrm{~mL})$ at $0^{\circ} \mathrm{C}$. This biphasic mixture was stirred vigorously for $8 \mathrm{~h}$ after which the aqueous layer was washed with $\mathrm{CH}_{2} \mathrm{Cl}_{2}(3 \times 50 \mathrm{~mL})$. The combined organic extracts were dried over $\mathrm{Na}_{2} \mathrm{SO}_{4}$, filtered and the filtrate was concentrated in vacuo. The residue was purified by column chromatography (silica gel, pentane/Et ${ }_{2} \mathrm{O}, 4 / 1$ ). The product-containing fractions were combined and the solvent was removed in vacuo to yield $201 \mathrm{mg}(89 \%)$ of $\mathbf{1 2}$ as a white solid. ${ }^{4}$

\section{Data for 12:}

${ }^{1}$ H NMR: $\quad\left(500 \mathrm{MHz}, \mathrm{CHCl}_{3}\right)$

7.96 (d, $J=7.3,2$ H, 2 x HC(2”)), 7.59 (t, $J=7.3,1 \mathrm{H}, \mathrm{HC}(4 ”))$, 7.49-7.44 (m, 4 $\left.\left.\mathrm{H}, 2 \times \mathrm{HC}\left(3^{\prime \prime \prime}\right)\right)+2 \times \mathrm{HC}\left(2^{\prime}\right)\right), 7.39\left(\mathrm{t}, J=7.6,2 \mathrm{H}, 2 \times \mathrm{HC}\left(3^{\prime}\right)\right), 7.31(\mathrm{t}, J=7.3$, $\left.1 \mathrm{H}, \mathrm{HC}\left(4^{\prime}\right)\right), 5.36$ (t, $\left.J=6.0,1 \mathrm{H}, \mathrm{HC}(1)\right), 3.79$ (br s, $\left.1 \mathrm{H}, \mathrm{OH}\right), 3.38$ (d, $J=5.9$, $\left.2 \mathrm{H}, \mathrm{H}_{2} \mathrm{C}(2)\right)$

SFC: $\quad(R)-\mathbf{1 2} t_{\mathrm{R}} 5.23 \mathrm{~min}(99.5 \%) ;(S)-\mathbf{1 2} t_{\mathrm{R}} 5.85 \min (0.5 \%)$ (Welko column, $125 \mathrm{bar}$, $3.0 \mathrm{~mL} / \mathrm{min}, 7.0 \% \mathrm{MeOH})$ 


\section{Survey of Amine Bases as Additives}

Reaction of 4 and Benzaldehyde with 1.0 equiv of 2,4,6-tri-tert-Butylpyridine (11) [JRH-II28]

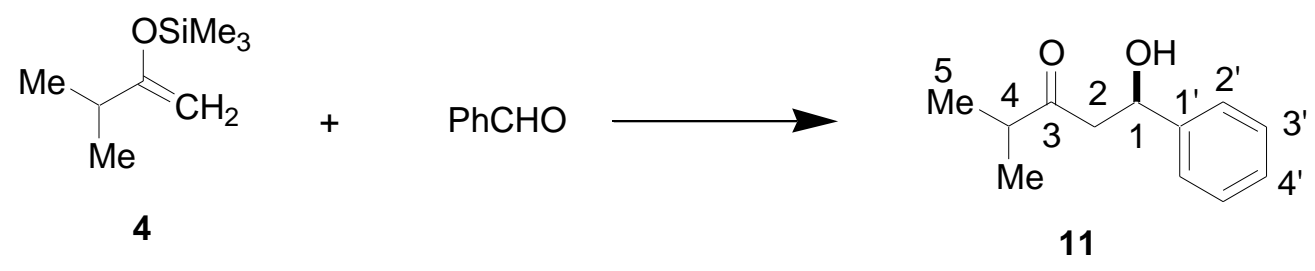

2,4,6-tri-tert-Butylpyridine (124 mg, $0.5 \mathrm{mmol}, 1.0$ equiv) was added to a flame-dried, 5$\mathrm{mL}$, 2-neck flask under $\mathrm{N}_{2}$ containing a solution of $21 \mathrm{mg}(0.025 \mathrm{mmol}, 0.05$ equiv $)$ of bisphosphoramide $(R, R)-7$ in $\mathrm{CH}_{2} \mathrm{Cl}_{2}(0.5 \mathrm{~mL})$. To this solution was added $51 \mu \mathrm{L}(0.5 \mathrm{mmol})$ of benzaldehyde in one portion. To the resulting mixture was added $86 \mu \mathrm{L}(0.75 \mathrm{mmol}, 1.5$ equiv) of $\mathrm{SiCl}_{4}$ in one portion and the reaction mixture was cooled to $-78{ }^{\circ} \mathrm{C}$ (bath temperature) over $15 \mathrm{~min}$. Then, $119 \mu \mathrm{L}$ (95 mg, $0.6 \mathrm{mmol}, 1.2$ equiv) of 4 was added dropwise over $5 \mathrm{~min}$. The resulting mixture was stirred at $-78{ }^{\circ} \mathrm{C}$ for $2 \mathrm{~h}$, whereupon $3 \mathrm{~mL}$ of chilled $\mathrm{CH}_{2} \mathrm{Cl}_{2}$ was added before the cold reaction mixture was poured into a rapidly stirring solution of $1 / 1$ sat. aq. $\mathrm{NaHCO}_{3} / \mathrm{sat}$. aq. $\mathrm{KF}(25 \mathrm{~mL})$ at $0^{\circ} \mathrm{C}$. This biphasic mixture was stirred vigorously for $8 \mathrm{~h}$ after which the aqueous layer was washed with $\mathrm{CH}_{2} \mathrm{Cl}_{2}(3 \times 50 \mathrm{~mL})$. The combined organic extracts were dried over $\mathrm{Na}_{2} \mathrm{SO}_{4}$, filtered and the filtrate was concentrated in vacuo. The residue was purified by column chromatography (pentane/Et $2 \mathrm{O} 4 / 1$ ). The product-containing fractions were combined and the solvent was removed in vacuo to yield $94 \mathrm{mg}(98 \%)$ of $\mathbf{1 1}$ as a clear, colorless oil. $^{4}$

\section{Data for 11:}

${ }^{1}$ H NMR: $\quad\left(500 \mathrm{MHz}, \mathrm{CHCl}_{3}\right)$

7.38-7.26 (m, $5 \mathrm{H}, \mathrm{H}(\operatorname{aryl})), 5.11(\mathrm{dt}, J=7.1,2.9,1 \mathrm{H}, \mathrm{HC}(1)), 3.45$ (d, $J=2.9,1$ $\mathrm{H}, \mathrm{OH}), 2.87$ (m, $2 \mathrm{H}, \mathrm{HC}(2)), 2.59$ (sept, $\left.J=6.8,1 \mathrm{H}, \mathrm{H}_{2} \mathrm{C}(4)\right), 1.10$ (d, J = 7.1, 6 $\left.\mathrm{H}, 2 \times \mathrm{H}_{3} \mathrm{C}(5)\right)$

SFC: $\quad(R)-\mathbf{1 1} t_{\mathrm{R}} 2.52 \min (99.0 \%) ;(S)-\mathbf{1 1} t_{\mathrm{R}} 2.80 \min (1.0 \%)$ (AD column, 125 bar, 3.0 $\mathrm{mL} / \mathrm{min}, 7.0 \% \mathrm{MeOH})$ 
Reaction of 4 and Benzaldehyde with 0.2 equiv of 2,4,6-tri-tert-Butylpyridine (11) [JRH-II31]

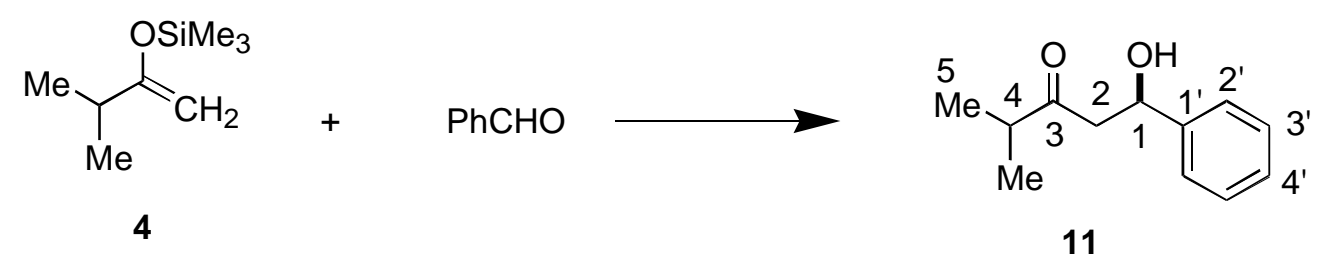

2,4,6-tri-tert-Butylpyridine ( $25 \mathrm{mg}, 0.1 \mathrm{mmol}, 0.2$ equiv) was added to a flame-dried, 5$\mathrm{mL}$, 2-neck flask under $\mathrm{N}_{2}$ containing a solution of $21 \mathrm{mg}(0.025 \mathrm{mmol}, 0.05$ equiv $)$ of bisphosphoramide $(R, R)-7$ in $\mathrm{CH}_{2} \mathrm{Cl}_{2}(0.5 \mathrm{~mL})$. Into this reaction mixture $512 \mu \mathrm{L}(0.5 \mathrm{mmol})$ of benzaldehyde was added in one portion. To this solution was added $86 \mu \mathrm{L}(0.75 \mathrm{mmol}, 1.5$ equiv) of $\mathrm{SiCl}_{4}$ in one portion and the reaction mixture was cooled to $-78{ }^{\circ} \mathrm{C}$ (bath temperature) over $15 \mathrm{~min}$. Then, $119 \mu \mathrm{L}$ (95 mg, $0.6 \mathrm{mmol}, 1.2$ equiv) of 4 was added dropwise over $5 \mathrm{~min}$. The resulting mixture was stirred at $-78{ }^{\circ} \mathrm{C}$ for $2 \mathrm{~h}$, whereupon $3 \mathrm{~mL}$ of chilled $\mathrm{CH}_{2} \mathrm{Cl}_{2}$ was added before the cold reaction mixture was poured into a rapidly stirring solution of $1 / 1$ sat. aq. $\mathrm{NaHCO}_{3} / \mathrm{sat}$. aq. $\mathrm{KF}(25 \mathrm{~mL})$ at $0^{\circ} \mathrm{C}$. This biphasic mixture was stirred vigorously for $8 \mathrm{~h}$ after which the aqueous layer was washed with $\mathrm{CH}_{2} \mathrm{Cl}_{2}(3 \times 50 \mathrm{~mL})$. The combined organic extracts were dried over $\mathrm{Na}_{2} \mathrm{SO}_{4}$, filtered and the filtrate was concentrated in vacuo. The residue was purified by column chromatography (silica gel, pentane/Et $2 \mathrm{O}, 4 / 1$ ). The product-containing fractions were combined and the solvent was removed in vacuo to yield $95 \mathrm{mg}$ (98.5\%) of 11 as a clear, colorless oil. ${ }^{4}$

Data for 11:

${ }^{1}$ H NMR: $\quad\left(500 \mathrm{MHz}, \mathrm{CHCl}_{3}\right)$

7.38-7.26 (m, $5 \mathrm{H}, \mathrm{H}(\operatorname{aryl})), 5.15$ (dt, $J=8.3,3.4,1 \mathrm{H}, \mathrm{HC}(1)), 3.51$ (d, $J=2.9,1$ $\mathrm{H}, \mathrm{OH}), 2.87$ (m, $2 \mathrm{H}, \mathrm{HC}(2)), 2.59$ (sept, $\left.J=6.8,1 \mathrm{H}, \mathrm{H}_{2} \mathrm{C}(4)\right), 1.10$ (d, $J=6.8,6$ $\left.\mathrm{H}, 2 \times \mathrm{H}_{3} \mathrm{C}(5)\right)$

SFC: $\quad(R)-11 t_{\mathrm{R}} 2.59 \min (99.0 \%) ;(S)-11 t_{\mathrm{R}} 2.88 \min (1.0 \%)$ (AD column, 125 bar, 3.0 $\mathrm{mL} / \mathrm{min}, 7.0 \% \mathrm{MeOH})$ 


\section{Reaction of 4 and Benzaldehyde with 0.2 equiv of $i$-Pr ${ }_{2} \mathrm{NEt}(11) \quad$ [JRH-II-34]}

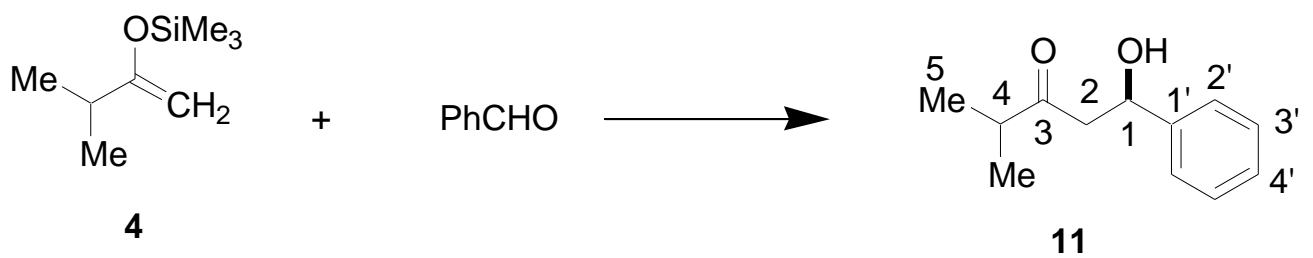

Diisopropylethylamine ( $18 \mu \mathrm{L}, 0.1 \mathrm{mmol}, 0.2$ equiv) was added via syringe to a flamedried, 5-mL, 2-neck flask under $\mathrm{N}_{2}$ containing a solution of $21 \mathrm{mg}(0.025 \mathrm{mmol}, 0.05$ equiv) of bisphosphoramide $(R, R)-7$ in $\mathrm{CH}_{2} \mathrm{Cl}_{2}(0.5 \mathrm{~mL})$. Into this reaction mixture was added $51 \mu \mathrm{L}(0.5$ mmol) of benzaldehyde in one portion. To the resulting mixture was added $86 \mu \mathrm{L}(0.75 \mathrm{mmol}$, 1.5 equiv) of $\mathrm{SiCl}_{4}$ and the reaction mixture was cooled to $-78{ }^{\circ} \mathrm{C}$ (bath temperature) over 15 min. Then, $119 \mu \mathrm{L}$ (95 mg, $0.6 \mathrm{mmol}, 1.2$ equiv) of 4 was added dropwise over $5 \mathrm{~min}$. The resulting mixture was stirred at $-78{ }^{\circ} \mathrm{C}$ for $3 \mathrm{~h}$ whereupon $2.5 \mathrm{~mL}$ of chilled $\mathrm{CH}_{2} \mathrm{Cl}_{2}$ was added before the cold reaction mixture was poured into a rapidly stirring solution of $1 / 1$ sat. aq. $\mathrm{NaHCO}_{3} /$ sat. aq. $\mathrm{KF}(25 \mathrm{~mL})$ at $0^{\circ} \mathrm{C}$. This biphasic mixture was stirred vigorously for $8 \mathrm{~h}$ after which the aqueous layer was washed with $\mathrm{CH}_{2} \mathrm{Cl}_{2}(3 \times 50 \mathrm{~mL})$. The combined organic extracts were dried over $\mathrm{Na}_{2} \mathrm{SO}_{4}$, filtered and the filtrate was concentrated in vacuo. The residue was purified by column chromatography (silica gel, pentane/Et ${ }_{2} \mathrm{O}, 4 / 1$ ). The product-containing fractions were combined and the solvent was removed in vacuo to yield $95 \mathrm{mg}$ (99\%) of $\mathbf{1 1}$ as a clear, colorless oil. ${ }^{4}$

\section{Data for 11:}

${ }^{1}$ H NMR: $\quad\left(500 \mathrm{MHz}, \mathrm{CHCl}_{3}\right)$

7.38-7.26 (m, $5 \mathrm{H}, \mathrm{H}(\operatorname{aryl})), 5.16$ (dt, $J=8.9,3.2,1 \mathrm{H}, \mathrm{HC}(1)), 3.51$ (d, $J=3.0,1$ $\mathrm{H}, \mathrm{OH}), 2.88(\mathrm{~m}, 2 \mathrm{H}, \mathrm{HC}(2)), 2.59$ (sept, $\left.J=6.8,1 \mathrm{H}, \mathrm{H}_{2} \mathrm{C}(4)\right), 1.10$ (d, $J=6.8,6$ $\left.\mathrm{H}, 2 \times \mathrm{H}_{3} \mathrm{C}(5)\right)$

SFC: $\quad(R)-\mathbf{1 1} t_{\mathrm{R}} 2.57 \mathrm{~min}(99.0 \%) ;(S)-\mathbf{1 1} t_{\mathrm{R}} 2.86 \mathrm{~min}(1.0 \%)$ (AD column, $125 \mathrm{bar}, 3.0$ $\mathrm{mL} / \mathrm{min}, 7.0 \% \mathrm{MeOH}$ ) 


\section{Reaction of 4 and Benzaldehyde with 0.1 equiv of $i$-Pr ${ }_{2} \mathrm{NEt}(11) \quad$ [JRH-II-35]}

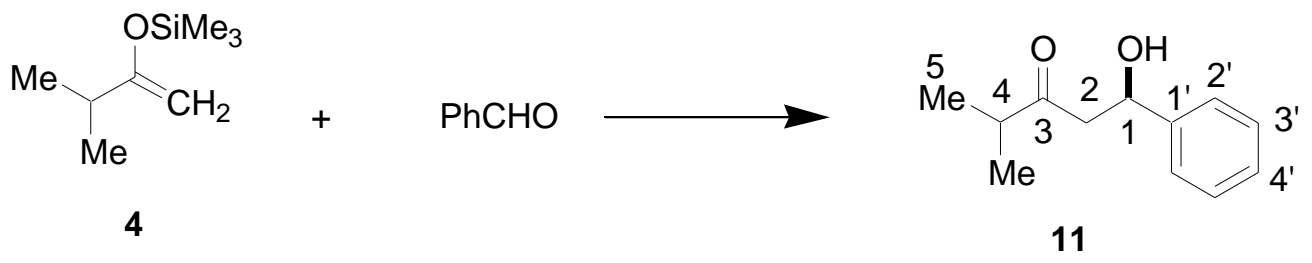

Diisopropylethylamine ( $9 \mu \mathrm{L}, 0.05 \mathrm{mmol}, 0.1$ equiv) was added via syringe to a flamedried, 5-mL, 2-neck flask under $\mathrm{N}_{2}$ containing a solution of $21 \mathrm{mg}(0.025 \mathrm{mmol}, 0.05$ equiv) of bisphosphoramide $(R, R)-7$ in $\mathrm{CH}_{2} \mathrm{Cl}_{2}(0.5 \mathrm{~mL})$. Into this reaction mixture was added $51 \mu \mathrm{L}(0.5$ mmol) of benzaldehyde in one portion. To this resulting mixture $86 \mu \mathrm{L}(0.75 \mathrm{mmol}, 1.5$ equiv) of $\mathrm{SiCl}_{4}$ and the reaction mixture was cooled to $-78^{\circ} \mathrm{C}$ (bath temperature) over $15 \mathrm{~min}$. Then, $119 \mu \mathrm{L}$ (95 mg, $0.6 \mathrm{mmol}, 1.2$ equiv) of 4 was added dropwise over $5 \mathrm{~min}$. The resulting mixture was stirred at $-78{ }^{\circ} \mathrm{C}$ for $3 \mathrm{~h}$ whereupon $2.5 \mathrm{~mL}$ of chilled $\mathrm{CH}_{2} \mathrm{Cl}_{2}$ was added before the cold reaction mixture was poured into a rapidly stirring solution of $1 / 1$ sat. aq. $\mathrm{NaHCO}_{3} /$ sat. aq. $\mathrm{KF}(25 \mathrm{~mL})$ at $0^{\circ} \mathrm{C}$. This biphasic mixture was stirred vigorously for $8 \mathrm{~h}$ after which the aqueous layer was washed with $\mathrm{CH}_{2} \mathrm{Cl}_{2}(3 \times 50 \mathrm{~mL})$. The combined organic extracts were dried over $\mathrm{Na}_{2} \mathrm{SO}_{4}$, filtered and the filtrate was concentrated in vacuo. The residue was purified by column chromatography (pentane/Et ${ }_{2} \mathrm{O} 4 / 1$ ). The product-containing fractions were combined and the solvent was removed in vacuo to yield $94 \mathrm{mg}(98 \%)$ of $\mathbf{1 1}$ as a clear, colorless oil. ${ }^{4}$

\section{Data for 11:}

${ }^{1}$ H NMR: $\quad\left(500 \mathrm{MHz}, \mathrm{CHCl}_{3}\right)$

7.38-7.26 (m, $5 \mathrm{H}, \mathrm{H}(\operatorname{aryl})), 5.15$ (dt, $J=8.3,3.2,1 \mathrm{H}, \mathrm{HC}(1)), 3.51$ (d, $J=3.2,1$ H, OH), 2.89 (m, 2 H, $\mathrm{HC}(2)), 2.59$ (sept, $\left.J=6.8,1 \mathrm{H}, \mathrm{H}_{2} \mathrm{C}(4)\right), 1.10$ (d, $J=6.8,6$ $\left.\mathrm{H}, 2 \times \mathrm{H}_{3} \mathrm{C}(5)\right)$

SFC: $\quad(R)-11 t_{\mathrm{R}} 2.62 \mathrm{~min}(99.0 \%) ;(S)-\mathbf{1 1} t_{\mathrm{R}} 2.90 \mathrm{~min}(1.0 \%)$ (AD column, $125 \mathrm{bar}, 3.0$ $\mathrm{mL} / \mathrm{min}, 7.0 \% \mathrm{MeOH}$ ) 


\section{Reaction of 4 and Benzaldehyde with 0.05 equiv of $i$-Pr ${ }_{2}$ NEt (11) [JRH-II-47]}

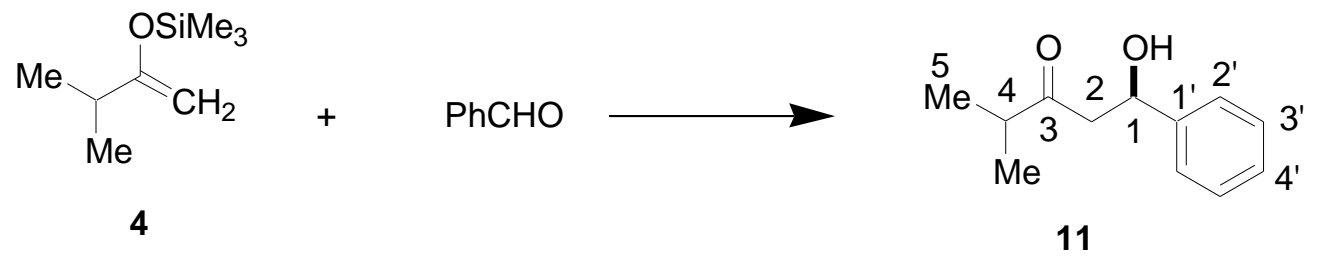

Diisopropylethylamine ( $9 \mu \mathrm{L}, 0.025 \mathrm{mmol}, 0.05$ equiv) was added via syringe to a flamedried, 5-mL, 2-neck flask under $\mathrm{N}_{2}$ containing a solution of $42 \mathrm{mg}$ ( $0.05 \mathrm{mmol}, 0.05$ equiv) of bisphosphoramide $(R, R)-7$ in $\mathrm{CH}_{2} \mathrm{Cl}_{2}(0.5 \mathrm{~mL})$. Into this reaction mixture was added $102 \mu \mathrm{L}(1.0$ mmol) of benzaldehyde in one portion. To this resulting mixture $172 \mu \mathrm{L}$ (1.5 mmol, 1.5 equiv) of $\mathrm{SiCl}_{4}$ and the reaction mixture was cooled to $-78{ }^{\circ} \mathrm{C}$ (bath temperature) over $15 \mathrm{~min}$. Then, $237 \mu \mathrm{L}$ (190 mg, $1.2 \mathrm{mmol}, 1.2$ equiv) of 4 was added dropwise over $5 \mathrm{~min}$. The resulting mixture was stirred at $-78{ }^{\circ} \mathrm{C}$ for $3 \mathrm{~h}$ whereupon $2.5 \mathrm{~mL}$ of chilled $\mathrm{CH}_{2} \mathrm{Cl}_{2}$ was added before the cold reaction mixture was poured into a rapidly stirring solution of $1 / 1$ sat. aq. $\mathrm{NaHCO}_{3} /$ sat. aq. $\mathrm{KF}(25 \mathrm{~mL})$ at $0^{\circ} \mathrm{C}$. This biphasic mixture was stirred vigorously for $8 \mathrm{~h}$ after which the aqueous layer was washed with $\mathrm{CH}_{2} \mathrm{Cl}_{2}(3 \times 50 \mathrm{~mL})$. The combined organic extracts were dried over $\mathrm{Na}_{2} \mathrm{SO}_{4}$, filtered and the filtrate was concentrated in vacuo. The residue was purified by column chromatography (silica gel, pentane/Et $2 \mathrm{O}, 4 / 1$ ). The product-containing fractions were combined and the solvent was removed in vacuo to yield $188 \mathrm{mg}(96 \%)$ of $\mathbf{1 1}$ as a clear, colorless oil. ${ }^{4}$

Data for 11:

${ }^{1}$ H NMR: $\quad\left(500 \mathrm{MHz}, \mathrm{CHCl}_{3}\right)$

7.38-7.26 (m, $5 \mathrm{H}, \mathrm{H}(\operatorname{aryl})$ ), 5.15 (dd, $J=8.6,3.9,1 \mathrm{H}, \mathrm{HC}(1)$ ), 3.46 (br s, $1 \mathrm{H}$, OH), 2.88 (m, $2 \mathrm{H}, \mathrm{HC}(2)), 2.59$ (sept, $\left.J=7.0,1 \mathrm{H}, \mathrm{H}_{2} \mathrm{C}(4)\right), 1.10$ (d, $J=6.8,6$ $\left.\mathrm{H}, 2 \times \mathrm{H}_{3} \mathrm{C}(5)\right)$

SFC: $\quad(R)-11 t_{\mathrm{R}} 2.54 \min (98.5 \%) ;(S)-11 t_{\mathrm{R}} 2.804 \min (1.5 \%)$ (AD column, $125 \mathrm{bar}, 3.0$ $\mathrm{mL} / \mathrm{min}, 7.0 \% \mathrm{MeOH})$ 


\section{Reaction of 2 and Benzaldehyde with 1 mol \% of $(R, R)-7$ (9) [JRH-II-66]}

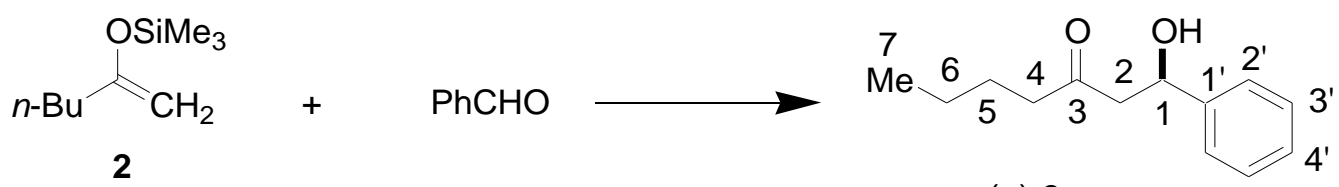

$(+)-9$

Diisopropylethylamine ( $18 \mu \mathrm{L}, 0.1 \mathrm{mmol}, 0.1$ equiv) was added via syringe to a flamedried, 5-mL, 2-neck flask under $\mathrm{N}_{2}$ containing a solution of $8.4 \mathrm{mg}(0.01 \mathrm{mmol}, 0.01$ equiv) of bisphosphoramide $(R, R)-7$ in $\mathrm{CH}_{2} \mathrm{Cl}_{2}(2 \mathrm{~mL})$. Into this reaction mixture was added $102 \mu \mathrm{L}(1.0$ mmol, 1.0 equiv) of benzaldehyde in one portion. To the resulting mixture was added $172 \mu \mathrm{L}$ (1.5 mmol, 1.5 equiv) of $\mathrm{SiCl}_{4}$ in one portion and the reaction mixture was cooled to $-72{ }^{\circ} \mathrm{C}$ over $15 \mathrm{~min}$. Then, $206 \mathrm{mg}$ ( $1.2 \mathrm{mmol}, 1.2$ equiv) of 2 was added dropwise neat over $5 \mathrm{~min}$. The resulting mixture was allowed to stir at $-72{ }^{\circ} \mathrm{C}$ for $3 \mathrm{~h}$ whereupon $2.5 \mathrm{~mL}$ of chilled $\mathrm{CH}_{2} \mathrm{Cl}_{2}$ was added before the cold reaction mixture was poured into a rapidly stirring solution of $1 / 1$ sat. aq. $\mathrm{NaHCO}_{3} /$ sat. aq. $\mathrm{KF}(25 \mathrm{~mL})$ at $0^{\circ} \mathrm{C}$. This biphasic mixture was stirred vigorously for $8 \mathrm{~h}$ after which the aqueous layer was washed with $\mathrm{CH}_{2} \mathrm{Cl}_{2}(3 \times 50 \mathrm{~mL})$. The combined organic extracts were dried over $\mathrm{Na}_{2} \mathrm{SO}_{4}$, filtered and the filtrate was concentrated in vacuo. The residue was purified by column chromatography (silica gel, pentane/ $\mathrm{Et}_{2} \mathrm{O}, 4 / 1$ ). The product-containing fractions were combined and the solvent was removed in vacuo to yield $198 \mathrm{mg}(96 \%)$ of (+)-9 as a clear, colorless oil. ${ }^{4}$

\section{Data for $(+)-13:$}

${ }^{1}$ H NMR: $\quad\left(500 \mathrm{MHz}, \mathrm{CHCl}_{3}\right.$ )

7.36-7.25 (m, 5 H, H(aryl)), 5.15 (dd, $J=9.0,3.3,1 \mathrm{H}, \mathrm{HC}(1)), 3.43$ (br s, $1 \mathrm{H}$, $\mathrm{OH}), 2.84\left(\underline{\mathrm{ABX}}, J_{\mathrm{AB}}=17.4, \mathrm{~J}_{\mathrm{AX}}=9.6,1 \mathrm{H}, \mathrm{H}_{a} \mathrm{C}(2)\right), 2.78\left(\mathrm{ABX}, J_{\mathrm{AB}}=17.4, J_{\mathrm{BX}}\right.$ $\left.=2.8,1 \mathrm{H}, \mathrm{H}_{b} \mathrm{C}(2)\right), 2.42$ (t, $J=7.3,2 \mathrm{H}, \mathrm{H}_{2} \mathrm{C}(4)$ ), 1.56 (quint, $J=7.5,2 \mathrm{H}$, $\left.\mathrm{H}_{2} \mathrm{C}(5)\right), 1.30$ (sext, $\left.J=7.4,2 \mathrm{H}, \mathrm{H}_{2} \mathrm{C}(6)\right), 0.90$ (t, $J=7.3,3 \mathrm{H}, \mathrm{H}_{3} \mathrm{C}(7)$ ) 
${ }^{13} \mathrm{C} \mathrm{NMR}: \quad\left(126 \mathrm{MHz}, \mathrm{CHCl}_{3}\right)$

$211.36(\mathrm{C}(3)), 142.87\left(\mathrm{C}\left(1^{\prime}\right)\right), 128.30\left(\mathrm{C}\left(3^{\prime}\right)\right), 127.39\left(\mathrm{C}\left(4^{\prime}\right)\right), 125.47\left(\mathrm{C}\left(2^{\prime}\right)\right)$, $69.73(\mathrm{C}(1)), 50.91(\mathrm{C}(2)), 43.23(\mathrm{C}(4)), 25.41(\mathrm{C}(5)), 22.06(\mathrm{C}(6)), 13.67(\mathrm{C}(7))$

Opt. Rot.: $\quad[\alpha]_{\mathrm{D}}^{24}+30.28(\mathrm{c}=2.20$, EtOH $)$

$[\alpha]_{\mathrm{D}}^{24}+71.99\left(\mathrm{c}=1.10, \mathrm{CHCl}_{3}\right)$

SFC: $\quad(R)-9 t_{\mathrm{R}} 4.21 \min (99.5 \%) ;(S)-9 t_{\mathrm{R}} 4.65 \min (0.5 \%)$ (AD column, 125 bar, 2.5 $\mathrm{mL} / \mathrm{min}, 5.0 \% \mathrm{MeOH}$ )

\section{Survey of Silyl Enol Ethers with Benzaldehyde.}

(+)-(R)-4-Hydroxy-4-phenyl-2-butanone (8) [JRH-II-62]

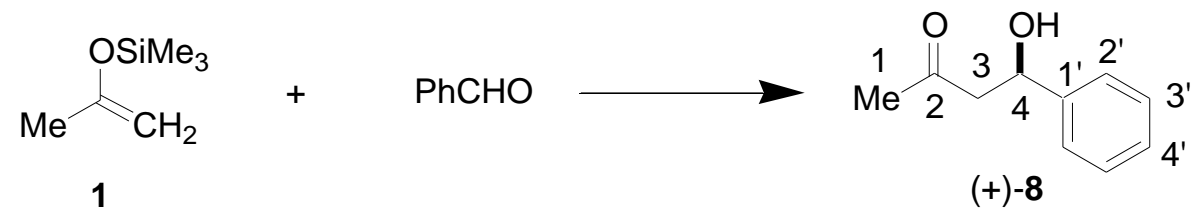

Diisopropylethylamine ( $18 \mu \mathrm{L}, 0.1 \mathrm{mmol}, 0.1$ equiv) was added via syringe to a flamedried, 5-mL, 2-neck flask under $\mathrm{N}_{2}$ containing a solution of $42 \mathrm{mg}(0.05 \mathrm{mmol}, 0.05$ equiv) of bisphosphoramide $(R, R)-7$ in $\mathrm{CH}_{2} \mathrm{Cl}_{2}(2 \mathrm{~mL})$. To this solution was added $102 \mu \mathrm{L}(1.0 \mathrm{mmol})$ of benzaldehyde in one portion. To the resulting solution was added $172 \mu \mathrm{L}$ ( $1.5 \mathrm{mmol}, 1.5$ equiv) of $\mathrm{SiCl}_{4}$ in one portion and the reaction mixture was cooled to $-72{ }^{\circ} \mathrm{C}$ over $15 \mathrm{~min}$. Then, 198 $\mu \mathrm{L}$ (156 mg, $1.2 \mathrm{mmol}, 1.2$ equiv) of $\mathbf{1}$ was added dropwise over $5 \mathrm{~min}$. The resulting mixture was stirred at $-72{ }^{\circ} \mathrm{C}$ for $3 \mathrm{~h}$, whereupon $2.5 \mathrm{~mL}$ of chilled $\mathrm{CH}_{2} \mathrm{Cl}_{2}$ was added before the cold reaction mixture was poured into a rapidly stirring solution of $1 / 1$ sat. aq. $\mathrm{NaHCO}_{3} /$ sat. aq. $\mathrm{KF}$ $(25 \mathrm{~mL})$ at $0^{\circ} \mathrm{C}$. This biphasic mixture was stirred vigorously for $8 \mathrm{~h}$ after which the aqueous layer was washed with $\mathrm{CH}_{2} \mathrm{Cl}_{2}(3 \times 50 \mathrm{~mL})$. The combined organic extracts were dried over $\mathrm{Na}_{2} \mathrm{SO}_{4}$, filtered and the filtrate was concentrated in vacuo. The residue was purified by column chromatography (silica gel, pentane/ $\mathrm{Et}_{2} \mathrm{O}, 1 / 1$ ). The product-containing fractions were combined and the solvent was removed in vacuo to yield $159 \mathrm{mg}(97 \%)$ of (+)-8 as a clear, colorless oil. ${ }^{4}$ 


\section{Data for (+)-8:}

${ }^{1} \mathrm{H}$ NMR: $\quad\left(500 \mathrm{MHz}, \mathrm{CHCl}_{3}\right)$

7.37-7.26 (m, $5 \mathrm{H}, \mathrm{H}(\operatorname{aryl})), 5.16$ (dt, $J=9.3,3.2,1 \mathrm{H}, \mathrm{HC}(4)), 3.7$ (d, $J=2.9,1$ $\mathrm{H}, \mathrm{OH}), 2.89\left(\underline{\mathrm{ABX}}, J_{\mathrm{AB}}=17.8, J_{\mathrm{AX}}=9.6,1 \mathrm{H} \mathrm{H}_{a} \mathrm{C}(3)\right), 2.83\left(\underline{\mathrm{A}} \underline{\mathrm{XX}}, J_{\mathrm{AB}}=17.8\right.$, $\left.J_{\mathrm{BX}}=2.9,1 \mathrm{H}, \mathrm{H}_{b} \mathrm{C}(3)\right), 2.20\left(\mathrm{~s}, 3 \mathrm{H} \mathrm{H}_{3} \mathrm{C}(1)\right)$

${ }^{13}$ C NMR: $\quad(126 \mathrm{MHz})$ $208.94(\mathrm{C}(2)), 142.77\left(\mathrm{C}\left(1^{\prime}\right)\right), 128.38\left(\mathrm{C}\left(3^{\prime}\right)\right), 127.50\left(\mathrm{C}\left(4^{\prime}\right)\right), 125.51\left(\mathrm{C}\left(2^{\prime}\right)\right)$, $69.66(\mathrm{C}(4)), 51.86(\mathrm{C}(3)), 30.58(\mathrm{C}(1))$

Opt. Rot.: $\quad[\alpha]_{\mathrm{D}}^{24}+37.16(\mathrm{c}=2.10, \mathrm{EtOH})$

$[\alpha]_{\mathrm{D}}^{24}+74.22\left(\mathrm{c}=1.10, \mathrm{CHCl}_{3}\right)$

SFC: $\quad(R)-8 t_{\mathrm{R}} 3.13 \min (98.0 \%) ;(S)-8 t_{\mathrm{R}} 3.48 \min (2.0 \%)$ (AS column, 125 bar, 2.5 $\mathrm{mL} / \mathrm{min}, 5.0 \% \mathrm{MeOH})$

\section{(+)-(R)-1-Hydroxy-1-phenyl-3-heptanone (9) [JRH-II-60]}

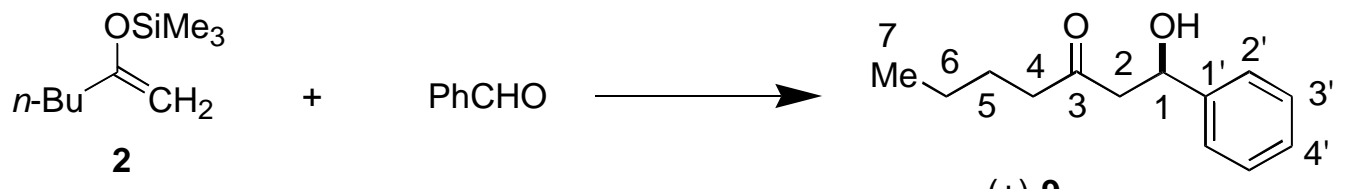

$(+)-9$

Diisopropylethylamine (18 $\mu \mathrm{L}, 0.1 \mathrm{mmol}, 0.1$ equiv) was added via syringe to a flamedried, 5-mL, 2-neck flask under $\mathrm{N}_{2}$ containing a solution of $42 \mathrm{mg}$ (0.05 mmol, 0.05 equiv) of bisphosphoramide $(R, R)-7$ in $\mathrm{CH}_{2} \mathrm{Cl}_{2}(2 \mathrm{~mL})$. To this solution was added $102 \mu \mathrm{L}(1.0 \mathrm{mmol})$ of benzaldehyde in one portion. To the resulting solution was added $172 \mu \mathrm{L}$ (1.5 mmol, 1.5 equiv) of $\mathrm{SiCl}_{4}$ in one portion and the reaction mixture was cooled to $-72{ }^{\circ} \mathrm{C}$ over $15 \mathrm{~min}$. Then, 206 $\mathrm{mg}$ (1.2 mmol, 1.2 equiv) of $\mathbf{2}$ was added dropwise neat over $5 \mathrm{~min}$. The resulting mixture was stirred at $-72{ }^{\circ} \mathrm{C}$ for $3 \mathrm{~h}$ whereupon $2.5 \mathrm{~mL}$ of chilled $\mathrm{CH}_{2} \mathrm{Cl}_{2}$ was added before the cold reaction mixture was poured into a rapidly stirring solution of $1 / 1$ sat. aq. $\mathrm{NaHCO}_{3} /$ sat. aq. $\mathrm{KF}(25 \mathrm{~mL})$ at $0^{\circ} \mathrm{C}$. This biphasic mixture was stirred vigorously for $8 \mathrm{~h}$ after which the aqueous layer was 
washed with $\mathrm{CH}_{2} \mathrm{Cl}_{2}(3 \times 50 \mathrm{~mL})$. The combined organic extracts were dried over $\mathrm{Na}_{2} \mathrm{SO}_{4}$, filtered and the filtrate was concentrated in vacuo. The residue was purified by column chromatography (silica gel, pentane/ $\mathrm{Et}_{2} \mathrm{O}, 4 / 1$ ). The product-containing fractions were combined and the solvent was removed in vacuo to yield $203 \mathrm{mg}(99 \%)$ of (+)-9 as a clear, colorless oil. ${ }^{4}$

Data for (+)-9:

${ }^{1}$ H NMR: $\quad\left(500 \mathrm{MHz}, \mathrm{CHCl}_{3}\right)$

7.37-7.26 (m, $5 \mathrm{H}, \mathrm{H}(\operatorname{aryl})), 5.16$ (dd, $J=8.8,3.4,1 \mathrm{H}, \mathrm{HC}(1)), 3.43$ (br s, $1 \mathrm{H}$, $\mathrm{OH}), 2.87\left(\underline{\mathrm{ABX}}, J_{\mathrm{AB}}=17.3, J_{\mathrm{AX}}=9.7,1 \mathrm{H}, \mathrm{H}_{a} \mathrm{C}(2)\right), 2.80\left(\mathrm{ABX}, J_{\mathrm{AB}}=17.3, J_{\mathrm{BX}}\right.$ $\left.=2.8,1 \mathrm{H}, \mathrm{H}_{b} \mathrm{C}(2)\right), 2.43\left(\mathrm{t}, J=7.3,2 \mathrm{H}, \mathrm{H}_{2} \mathrm{C}(4)\right), 1.57$ (quint, $J=7.3,2 \mathrm{H}$, $\left.\mathrm{H}_{2} \mathrm{C}(5)\right), 1.30$ (sext, $\left.J=7.3,2 \mathrm{H}, \mathrm{H}_{2} \mathrm{C}(6)\right), 0.90$ (t, $J=7.3,3 \mathrm{H}, \mathrm{H}_{3} \mathrm{C}(7)$ )

${ }^{13} \mathrm{C} \mathrm{NMR}: \quad\left(126 \mathrm{MHz}, \mathrm{CHCl}_{3}\right)$

$211.38(\mathrm{C}(3)), 142.91\left(\mathrm{C}\left(1^{\prime}\right)\right), 128.32\left(\mathrm{C}\left(3^{\prime}\right)\right), 127.41\left(\mathrm{C}\left(4^{\prime}\right)\right), 125.50\left(\mathrm{C}\left(2^{\prime}\right)\right)$, $69.75(\mathrm{C}(1)), 50.91(\mathrm{C}(2)), 43.22(\mathrm{C}(4)), 25.40(\mathrm{C}(5)), 22.03(\mathrm{C}(6)), 13.63(\mathrm{C}(7))$

Opt. Rot.: $\quad[\alpha]_{\mathrm{D}}^{24}+27.07(\mathrm{c}=1.10, \mathrm{EtOH})$

$[\alpha]_{\mathrm{D}}^{24}+69.09\left(\mathrm{c}=1.40, \mathrm{CHCl}_{3}\right)$

SFC: $\quad(R)-9 t_{\mathrm{R}} 4.21 \min (99.5 \%)$; $(S)-9 t_{\mathrm{R}} 4.65 \min (0.5 \%)$ (AD column, 125 bar, 2.5 $\mathrm{mL} / \mathrm{min}, 5.0 \% \mathrm{MeOH})$ 
(+)-(R)-1-Hydroxy-5-methyl-1-phenyl-3-hexanone (10) [JRH-II-65]

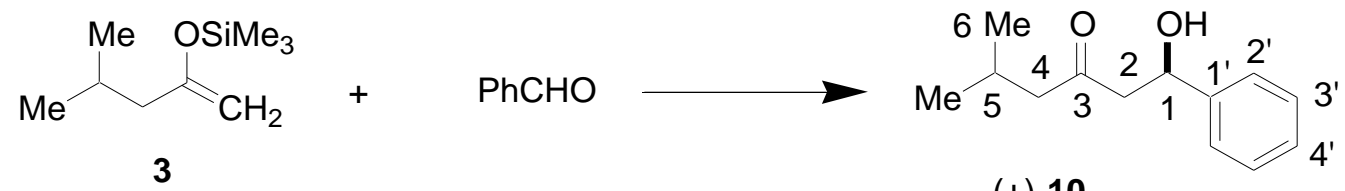

$(+)-10$

Diisopropylethylamine ( $18 \mu \mathrm{L}, 0.1 \mathrm{mmol}, 0.1$ equiv) was added via syringe to a flamedried, 5-mL, 2-neck flask under $\mathrm{N}_{2}$ containing a solution of $42 \mathrm{mg}$ (0.05 mmol, 0.05 equiv) of bisphosphoramide $(R, R)-7$ in $\mathrm{CH}_{2} \mathrm{Cl}_{2}(2 \mathrm{~mL})$. To this solution was added $102 \mu \mathrm{L}(1.0 \mathrm{mmol})$ of benzaldehyde in one portion. To the resulting solution was added $172 \mu \mathrm{L}(1.5 \mathrm{mmol}, 1.5$ equiv) of $\mathrm{SiCl}_{4}$ in one portion and the reaction mixture was cooled to $-72{ }^{\circ} \mathrm{C}$ over $15 \mathrm{~min}$. Then, 206 $\mathrm{mg}$ (1.2 mmol, 1.2 equiv) of $\mathbf{3}$ was added dropwise neat over $5 \mathrm{~min}$. The resulting mixture was stirred at $-72{ }^{\circ} \mathrm{C}$ for $3 \mathrm{~h}$ whereupon $2.5 \mathrm{~mL}$ of chilled $\mathrm{CH}_{2} \mathrm{Cl}_{2}$ was added before the cold reaction mixture was poured into a rapidly stirring solution of $1 / 1$ sat. aq. $\mathrm{NaHCO}_{3} /$ sat. aq. $\mathrm{KF}(25 \mathrm{~mL})$ at $0^{\circ} \mathrm{C}$. This biphasic mixture was stirred vigorously for $8 \mathrm{~h}$ after which the aqueous layer was washed with $\mathrm{CH}_{2} \mathrm{Cl}_{2}(3 \times 50 \mathrm{~mL})$. The combined organic extracts were dried over $\mathrm{Na}_{2} \mathrm{SO}_{4}$, filtered and the filtrate was concentrated in vacuo. The residue was purified by column chromatography (silica gel, pentane/ $\mathrm{Et}_{2} \mathrm{O}, 4 / 1$ ). The product-containing fractions were combined and the solvent was removed in vacuo to yield $202 \mathrm{mg}(98 \%)$ of (+)-10 as a clear, colorless oil. ${ }^{4}$

$\underline{\text { Data for }(+)-\mathbf{1 0}}$

${ }^{1} \mathrm{H}$ NMR: $\quad\left(500 \mathrm{MHz}, \mathrm{CHCl}_{3}\right)$

7.39-7.28 (m, $5 \mathrm{H}, \mathrm{H}(\operatorname{aryl})), 5.18$ (dd, $J=9.0,3.4,1 \mathrm{H}, \mathrm{HC}(1)), 3.35$ (br s, $1 \mathrm{H}$, $\mathrm{OH}), 2.85\left(\underline{\mathrm{ABX}}, J_{\mathrm{AB}}=17.4, J_{\mathrm{AX}}=9.6,1 \mathrm{H}, \mathrm{H}_{a} \mathrm{C}(2)\right), 2.80\left(\mathrm{AB} X, J_{\mathrm{AB}}=17.4, J_{\mathrm{BX}}\right.$ $\left.=2.8,1 \mathrm{H}, \mathrm{H}_{b} \mathrm{C}(2)\right), 2.30\left(\mathrm{~d}, J=7.1,2 \mathrm{H}, \mathrm{H}_{2} \mathrm{C}(4)\right), 2.17$ (septet, $J=6.7,1 \mathrm{H}$, $\left.\mathrm{H}_{2} \mathrm{C}(5)\right), 0.94\left(\mathrm{~d}, J=6.7,6 \mathrm{H}, 2 \times \mathrm{H}_{3} \mathrm{C}(6)\right)$

${ }^{13} \mathrm{C} \mathrm{NMR}: \quad\left(126 \mathrm{MHz}, \mathrm{CHCl}_{3}\right)$

211.05 (C(3)), 142.91 (C(1')), 128.34 (C(3’)), 127.43 (C(4')), 125.52 (C(2’)), $69.71(\mathrm{C}(1)), 52.45(\mathrm{C}(2)), 51.40(\mathrm{C}(4)), 24.23(\mathrm{C}(5)), 22.34(\mathrm{C}(6))$ 
Opt. Rot.: $\quad[\alpha]_{\mathrm{D}}^{24}+30.84(\mathrm{c}=2.40, \mathrm{EtOH})$

$$
[\alpha]_{\mathrm{D}}^{24}+58.30\left(\mathrm{c}=1.50, \mathrm{CHCl}_{3}\right)
$$

SFC: $\quad(R)-\mathbf{1 0} t_{\mathrm{R}} 2.76 \min (99.0 \%) ;(S)-\mathbf{1 0} t_{\mathrm{R}} 3.09 \min (1.0 \%)$ (AD column, 125 bar, 2.5 $\mathrm{mL} / \mathrm{min}, 7.0 \% \mathrm{MeOH})$

\section{(+)-(R)-1-Hydroxy-4-methyl-1-phenyl-3-pentanone (11) [JRH-II-64]}

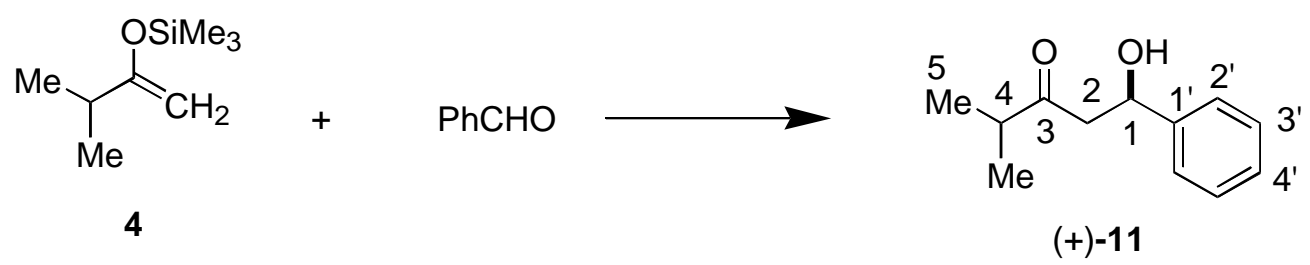

Diisopropylethylamine (18 $\mu \mathrm{L}, 0.1 \mathrm{mmol}, 0.1$ equiv) was added via syringe to a flamedried, 5-mL, 2-neck flask under $\mathrm{N}_{2}$ containing a solution of $42 \mathrm{mg}$ (0.05 mmol, 0.05 equiv) of bisphosphoramide $(R, R)-7$ in $\mathrm{CH}_{2} \mathrm{Cl}_{2}(2 \mathrm{~mL})$. To this solution was added $102 \mu \mathrm{L}(1.0 \mathrm{mmol})$ of benzaldehyde in one portion. To the resulting solution was added $172 \mu \mathrm{L}$ (1.5 mmol, 1.5 equiv) of $\mathrm{SiCl}_{4}$ and the reaction mixture was cooled to $-72{ }^{\circ} \mathrm{C}$ over $15 \mathrm{~min}$. Then, $237 \mu \mathrm{L}$ (190 $\mathrm{mg}, 1.2$ mmol, 1.2 equiv) of 4 was added dropwise over 5 min. The resulting mixture was stirred at -72 ${ }^{\circ} \mathrm{C}$ for $3 \mathrm{~h}$ whereupon $2.5 \mathrm{~mL}$ of chilled $\mathrm{CH}_{2} \mathrm{Cl}_{2}$ was added before the cold reaction mixture was poured into a rapidly stirring solution of $1 / 1$ sat. aq. $\mathrm{NaHCO}_{3} /$ sat. aq. $\mathrm{KF}(25 \mathrm{~mL})$ at $0^{\circ} \mathrm{C}$. This biphasic mixture was stirred vigorously for $8 \mathrm{~h}$ after which the aqueous layer was washed with $\mathrm{CH}_{2} \mathrm{Cl}_{2}(3 \times 50 \mathrm{~mL})$. The combined organic extracts were dried over $\mathrm{Na}_{2} \mathrm{SO}_{4}$, filtered and the filtrate was concentrated in vacuo. The residue was purified by column chromatography (pentane/Et ${ }_{2} \mathrm{O}$ 4/1). The product-containing fractions were combined and the solvent was removed in vacuo to yield $182 \mathrm{mg}(95 \%)$ of (+)-11 as a clear, colorless oil. ${ }^{4}$ 


\section{$\underline{\text { Data for }(+)-11:}$}

${ }^{1} \mathrm{H}$ NMR: $\quad\left(500 \mathrm{MHz}, \mathrm{CHCl}_{3}\right)$

7.34-7.25 (m, $5 \mathrm{H}, \mathrm{H}(\operatorname{aryl})), 5.11$ (dd, $J=9.2,3.2,1 \mathrm{H}, \mathrm{HC}(1)), 3.51$ (br s, $1 \mathrm{H}$, $\mathrm{OH}), 2.88\left(\underline{\mathrm{ABX}}, J_{\mathrm{AB}}=15.0, J_{\mathrm{AX}}=9.1,1 \mathrm{H}, \mathrm{H}_{a} \mathrm{C}(2)\right), 2.85\left(\mathrm{ABX}, J_{\mathrm{AB}}=15.0\right.$, $\left.\mathrm{J}_{\mathrm{BX}}=2.9,1 \mathrm{H}, \mathrm{H}_{b} \mathrm{C}(2)\right), 2.59$ (sept, $\left.J=7.0,1 \mathrm{H}, \mathrm{H}_{2} \mathrm{C}(4)\right), 1.10(\mathrm{~d}, J=6.8,6 \mathrm{H}, 2$ $\left.\mathrm{x}_{3} \mathrm{C}(5)\right)$

${ }^{13}$ C NMR: $\quad\left(126 \mathrm{MHz}, \mathrm{CHCl}_{3}\right)$ 215.02 (C(3)), $142.97\left(\mathrm{C}\left(1^{\prime}\right)\right), 128.35\left(\mathrm{C}\left(3^{\prime}\right)\right), 127.44\left(\mathrm{C}\left(4^{\prime}\right)\right), 125.53\left(\mathrm{C}\left(2^{\prime}\right)\right)$, $69.82(\mathrm{C}(1)), 48.68(\mathrm{C}(2)), 41.37(\mathrm{C}(4)), 17.70(\mathrm{C}(5))$

Opt. Rot.: $\quad[\alpha]_{\mathrm{D}}^{24}+29.19(\mathrm{c}=2.00, \mathrm{EtOH})$

$$
[\alpha]_{\mathrm{D}}^{24}+70.59\left(\mathrm{c}=1.60, \mathrm{CHCl}_{3}\right)
$$

SFC: $\quad(R)-11 t_{\mathrm{R}} 2.57 \min (99.5 \%) ;(S)-11 t_{\mathrm{R}} 2.88 \min (0.5 \%)$ (AD column, 125 bar, 2.5 $\mathrm{mL} / \mathrm{min}, 7.0 \% \mathrm{MeOH})$

\section{(+)-(R)-3-hydroxy-1,3-diphenyl-1-propanone (12) [JRH-II-67]}

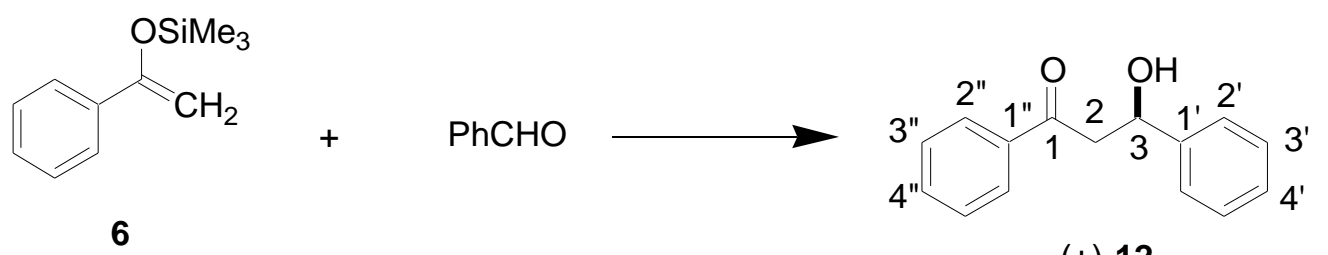

$(+)-12$

Diisopropylamine (18 $\mu \mathrm{L}, 0.1 \mathrm{mmol}, 0.1$ equiv) was added via syringe to a flame-dried, 5-mL, 2-neck flask under $\mathrm{N}_{2}$ containing a solution of $42 \mathrm{mg}(0.05 \mathrm{mmol}, 0.05$ equiv) of bisphosphoramide $(R, R)-7$ in $\mathrm{CH}_{2} \mathrm{Cl}_{2}(2 \mathrm{~mL})$. To this solution was added $102 \mu \mathrm{L}(1.0 \mathrm{mmol})$ of benzaldehyde in one portion. To the resulting solution was added $172 \mu \mathrm{L}(1.5 \mathrm{mmol}, 1.5$ equiv) of $\mathrm{SiCl}_{4}$ in one portion and the reaction mixture was cooled to $-72{ }^{\circ} \mathrm{C}$ over $15 \mathrm{~min}$. Then, 248 $\mu \mathrm{L}$ (231 mg, $1.2 \mathrm{mmol}, 1.2$ equiv) of $\mathbf{6}$ was added dropwise over $5 \mathrm{~min}$. The resulting mixture was stirred at $-72{ }^{\circ} \mathrm{C}$ for $3 \mathrm{~h}$ whereupon $2.5 \mathrm{~mL}$ of chilled $\mathrm{CH}_{2} \mathrm{Cl}_{2}$ was added before the cold 
reaction mixture was poured into a rapidly stirring solution of $1 / 1$ sat. aq. $\mathrm{NaHCO}_{3} /$ sat. aq. $\mathrm{KF}$ $(25 \mathrm{~mL})$ at $0^{\circ} \mathrm{C}$. This biphasic mixture was stirred vigorously for $8 \mathrm{~h}$ after which the aqueous layer was washed with $\mathrm{CH}_{2} \mathrm{Cl}_{2}(3 \times 50 \mathrm{~mL})$. The combined organic extracts were dried over $\mathrm{Na}_{2} \mathrm{SO}_{4}$, filtered and the filtrate was concentrated in vacuo. The residue was purified by column chromatography (silica gel, pentane/ $\mathrm{Et}_{2} \mathrm{O}, 4 / 1$ ). The product-containing fractions were combined and the solvent was removed in vacuo to yield $221 \mathrm{mg}(98 \%)$ of (+)-12 as a white solid. ${ }^{4}$

Data for $(+)-\mathbf{1 2}$ :

${ }^{1} \mathrm{H}$ NMR: $\quad\left(500 \mathrm{MHz}, \mathrm{CHCl}_{3}\right)$

7.96 (d, $J=7.5,2$ H, 2 x HC(2”)), 7.58 (t, $J=7.3,1 \mathrm{H}, \mathrm{HC}(4 ”)), 7.47-7.43$ (m, 4 $\left.\left.\mathrm{H}, 2 \times \mathrm{HC}\left(3^{\prime \prime}\right)^{\prime}\right)+2 \times \mathrm{HC}\left(2^{\prime}\right)\right), 7.39\left(\mathrm{t}, J=7.3,2 \mathrm{H}, 2 \times \mathrm{HC}\left(3^{\prime}\right)\right), 7.31(\mathrm{t}, J=7.5$, $\left.1 \mathrm{H}, \mathrm{HC}\left(4^{\prime}\right)\right), 5.35$ (dd, $\left.J=8.7,3.7,1 \mathrm{H}, \mathrm{HC}(1)\right), 3.79$ (br s, $\left.1 \mathrm{H}, \mathrm{OH}\right), 3.39$ $\left(\underline{\mathrm{ABX}}, J_{\mathrm{AB}}=17.6, \mathrm{~J}_{\mathrm{AX}}=9.3,1 \mathrm{H}, \mathrm{H}_{a} \mathrm{C}(2)\right), 3.35\left(\mathrm{ABX}, J_{\mathrm{AB}}=17.6, J_{\mathrm{BX}}=2.9,1\right.$ $\left.\mathrm{H}, \mathrm{H}_{b} \mathrm{C}(2)\right)$

${ }^{13} \mathrm{C} \mathrm{NMR}: \quad\left(126 \mathrm{MHz}, \mathrm{CHCl}_{3}\right)$

$199.92(\mathrm{C}(3)), 142.96\left(\mathrm{C}\left(1^{\prime}\right)\right), 136.43\left(\mathrm{C}\left(1^{\prime \prime}\right)\right), 133.45\left(\mathrm{C}\left(4^{\prime}\right)\right), 128.53\left(\mathrm{C}\left(2^{\prime}\right)\right)$, 128.39 (C(3’)), 128.03 (C(2’)), 127.48 (C(4’)), 125.64 (C(3”)), 69.82 (C(1)), $47.25(\mathrm{C}(2))$

Opt. Rot.: $\quad[\alpha]_{\mathrm{D}}^{24}+31.85(\mathrm{c}=1.80, \mathrm{EtOH})$ $[\alpha]_{\mathrm{D}}^{24}+68.85\left(\mathrm{c}=1.10, \mathrm{CHCl}_{3}\right)$

SFC: $\quad(R)-12 t_{\mathrm{R}} 5.21 \min (99.5 \%) ;(S)-12 t_{\mathrm{R}} 5.83 \min (0.5 \%)$ (Welko column, 125 bar, $3.0 \mathrm{~mL} / \mathrm{min}, 7.0 \% \mathrm{MeOH})$ 


\section{Survey of Aldehydes with Silyl Enol Ether 2.}

(+)-(R)-3-Hydroxy-1-phenyl-1-nonen-5-one (13) [JRH-II-97]

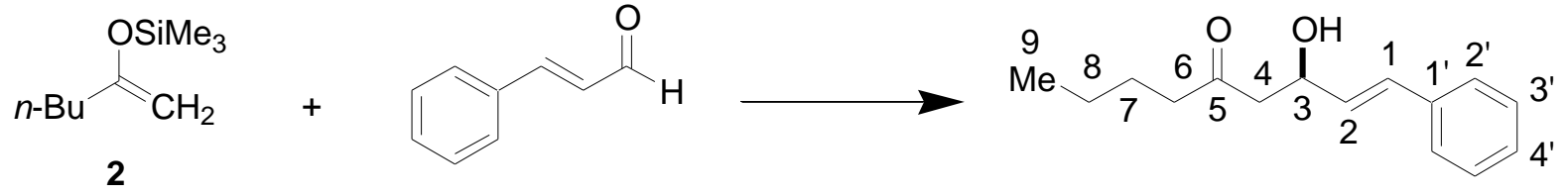

$(+)-13$

Diisopropylethylamine ( $18 \mu \mathrm{L}, 0.1 \mathrm{mmol}, 0.1$ equiv) was added via syringe, to a flamedried, 5-mL, Schlenk flask under $\mathrm{N}_{2}$ containing a solution of $42 \mathrm{mg}(0.05 \mathrm{mmol}, 0.05$ equiv) of bisphosphoramide $(R, R)-7$ in $\mathrm{CH}_{2} \mathrm{Cl}_{2}(2 \mathrm{~mL})$. To this solution was added $126 \mu \mathrm{L}$ (1.0 mmol) of cinnamaldehyde in one portion. To the resulting solution was added $172 \mu \mathrm{L}(1.5 \mathrm{mmol}, 1.5$ equiv) of $\mathrm{SiCl}_{4}$ in one portion and the reaction mixture was cooled to $-72{ }^{\circ} \mathrm{C}$ over $15 \mathrm{~min}$. Then, $206 \mathrm{mg}$ ( $1.2 \mathrm{mmol}, 1.2$ equiv) of 2 was added dropwise neat over $5 \mathrm{~min}$. The resulting mixture was stirred at $-72{ }^{\circ} \mathrm{C}$ for $4 \mathrm{~h}$ whereupon $3.0 \mathrm{~mL}$ of chilled $\mathrm{CH}_{2} \mathrm{Cl}_{2}$ was added before the cold reaction mixture was poured into a rapidly stirring solution of $1 / 1$ sat. aq. $\mathrm{NaHCO}_{3} /$ sat. aq. $\mathrm{KF}$ $(25 \mathrm{~mL})$ at $0^{\circ} \mathrm{C}$. This biphasic mixture was stirred vigorously for $4 \mathrm{~h}$ after which the aqueous layer was washed with $\mathrm{CH}_{2} \mathrm{Cl}_{2}(3 \times 50 \mathrm{~mL})$. The combined organic extracts were dried over $\mathrm{Na}_{2} \mathrm{SO}_{4}$, filtered and the filtrate was concentrated in vacuo. The residue was purified by column chromatography (silica gel, pentane/Et ${ }_{2} \mathrm{O}, 4 / 1$ ). The product-containing fractions were combined and the solvent was removed in vacuo to yield $226 \mathrm{mg}(97.5 \%)$ of (+)-13 as a clear, colorless oil. $^{4}$

Data for (+)-13:

${ }^{1} \mathrm{H}$ NMR: $\quad\left(500 \mathrm{MHz}, \mathrm{CHCl}_{3}\right)$ $7.37\left(\mathrm{dd}, J=8.1,1.0,2 \mathrm{H}, 2 \times \mathrm{HC}\left(2^{\prime}\right)\right), 7.31\left(\mathrm{dt}, J=7.5,1.5,2 \mathrm{H}, 2 \times \mathrm{HC}\left(3^{\prime}\right)\right)$, 7.25 (tt, $\left.J=7.3,1.6,1 \mathrm{H}, \mathrm{HC}\left(4^{\prime}\right)\right), 6.64$ (dd, $\left.J=15.9,1.1,1 \mathrm{H}, \mathrm{HC}(1)\right), 6.20$ (dd, $J=15.9,6.2,1 \mathrm{H}, \mathrm{HC}(2)), 4.76$ (m, $1 \mathrm{H}, \mathrm{HC}(3)), 3.18$ (d, $J=3.6,1 \mathrm{H}, \mathrm{OH}), 2.73$ (m, 2H, $\left.\mathrm{H}_{2} \mathrm{C}(4)\right), 2.46$ (t, $J=7.4,2 \mathrm{H}, \mathrm{H}_{2} \mathrm{C}(6)$ ), 1.58 (quint, $J=7.5,2 \mathrm{H}, \mathrm{H}_{2} \mathrm{C}(7)$ ), 1.33 (sext, $J=7.4,2 \mathrm{H}, \mathrm{H}_{2} \mathrm{C}(8)$ ), 0.91 (t, $J=7.3,3 \mathrm{H}, \mathrm{H}_{3} \mathrm{C}(9)$ ) 
${ }^{13} \mathrm{C}$ NMR: $\quad\left(126 \mathrm{MHz}, \mathrm{CHCl}_{3}\right)$

$211.08(\mathrm{C}(5)), 136.38\left(\mathrm{C}\left(1^{\prime}\right)\right), 130.33(\mathrm{C}(1)), 129.91(\mathrm{C}(2)), 128.35\left(\mathrm{C}\left(3^{\prime}\right)\right)$, $127.45\left(\mathrm{C}\left(4^{\prime}\right)\right), 126.27\left(\mathrm{C}\left(2^{\prime}\right)\right), 68.24$ (C(3)), 48.87 (C(4)), 43.21 (C(6)), 25.35 $(\mathrm{C}(7)), 21.99(\mathrm{C}(8)), 13.59(\mathrm{C}(9))$

Opt. Rot.: $\quad[\alpha]_{\mathrm{D}}^{24}+1.37(\mathrm{c}=1.80, \mathrm{EtOH})$ $[\alpha]_{\mathrm{D}}^{24}+23.70\left(\mathrm{c}=1.30, \mathrm{CHCl}_{3}\right)$

SFC: $\quad(R)-\mathbf{1 3} t_{\mathrm{R}} 3.28 \min (99.5 \%) ;(S)-\mathbf{1 3} t_{\mathrm{R}} 3.53 \mathrm{~min}(0.5 \%)$ (AD column, $125 \mathrm{bar}, 2.5$ $\mathrm{mL} / \mathrm{min}, 15.0 \% \mathrm{MeOH})$

\section{(+)-(R)-3-Hydroxyl-2-methyl-1-phenyl-1-nonen-5-one (14) [JRH-II-92]}

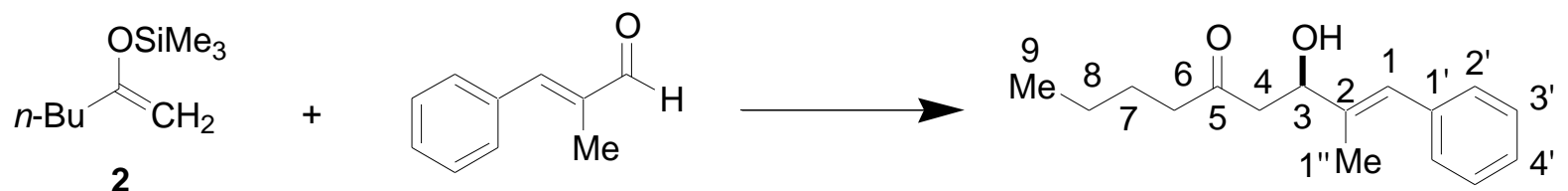

$(+)-14$

Diisopropylethylamine (18 $\mu \mathrm{L}, 0.1 \mathrm{mmol}, 0.1$ equiv) was added via syringe to a flamedried, 5-mL, Schlenk flask under $\mathrm{N}_{2}$ containing a solution of $84 \mathrm{mg}$ (0.05 mmol, 0.05 equiv) of bisphosphoramide $(R, R)-7$ in $\mathrm{CH}_{2} \mathrm{Cl}_{2}(2 \mathrm{~mL})$. To this solution was added $140 \mu \mathrm{L}(1.0 \mathrm{mmol})$ of (E)-2-methylcinnamaldehyde in one portion. To the resulting solution was added $172 \mu \mathrm{L}(1.5$ mmol, 1.5 equiv) of $\mathrm{SiCl}_{4}$ in one portion and the reaction mixture was cooled to $-60{ }^{\circ} \mathrm{C}$ over 15 min. Then, $206 \mathrm{mg}$ (1.2 mmol, 1.2 equiv) of 2 was added dropwise neat over $5 \mathrm{~min}$. The resulting mixture was allowed to stir at $-60{ }^{\circ} \mathrm{C}$ for $24 \mathrm{~h}$ whereupon $3.0 \mathrm{~mL}$ of chilled $\mathrm{CH}_{2} \mathrm{Cl}_{2}$ was added before the cold reaction mixture was poured into a rapidly stirring solution of $1 / 1$ sat. aq. $\mathrm{NaHCO}_{3} /$ sat. aq. $\mathrm{KF}(25 \mathrm{~mL})$ at $0^{\circ} \mathrm{C}$. This biphasic mixture was stirred vigorously for $4 \mathrm{~h}$ after which the aqueous layer was washed with $\mathrm{CH}_{2} \mathrm{Cl}_{2}(3 \times 50 \mathrm{~mL})$. The combined organic extracts were dried over $\mathrm{Na}_{2} \mathrm{SO}_{4}$, filtered and the filtrate was concentrated in vacuo. The residue was purified by column chromatography (silica gel, pentane/Et $2 \mathrm{O}, 4 / 1$ ). The product-containing 
fractions were combined and the solvent was removed in vacuo to yield $132 \mathrm{mg}(54 \%)$ of $\mathbf{1 4}$ as a clear, colorless oil. ${ }^{4}$

Data for $(+)-14:$

${ }^{1}$ H NMR: $\quad\left(500 \mathrm{MHz}, \mathrm{CHCl}_{3}\right)$

$7.33\left(\mathrm{t}, \mathrm{J}=7.5,2 \mathrm{H}, 2 \times \mathrm{HC}\left(2^{\prime}\right)\right), 7.27$ (d, J = 7.3, $\left.2 \mathrm{H}, 2 \times \mathrm{HC}\left(3^{\prime}\right)\right), 7.21(\mathrm{t}, \mathrm{J}=$ 7.3, $\left.1 \mathrm{H}, \mathrm{HC}\left(4^{\prime}\right)\right), 6.57$ (s, $\left.1 \mathrm{H}, \mathrm{HC}(1)\right), 4.63$ (dd, $\left.J=7.3,4.5,1 \mathrm{H}, \mathrm{HC}(3)\right), 3.12$ (s, $1 \mathrm{H}, \mathrm{OH}), 2.73\left(\mathrm{~m}, 2 \mathrm{H}, \mathrm{H}_{2} \mathrm{C}(4)\right), 2.48$ (t, $\left.J=7.4,2 \mathrm{H}, \mathrm{H}_{2} \mathrm{C}(6)\right), 1.88$ (s, $3 \mathrm{H}$, $\mathrm{H}_{3} \mathrm{C}\left(1\right.$ ()), 1.59 (quint, $J=7.4,2 \mathrm{H}, \mathrm{H}_{2} \mathrm{C}(7)$ ), 1.33 (sext, $J=7.4,2 \mathrm{H}, \mathrm{H}_{2} \mathrm{C}(8)$ ), $0.92\left(\mathrm{t}, J=7.4,3 \mathrm{H}, \mathrm{H}_{3} \mathrm{C}(9)\right)$

${ }^{13} \underline{\mathrm{C} \mathrm{NMR}}: \quad\left(126 \mathrm{MHz}, \mathrm{CHCl}_{3}\right)$ 211.96 (C(5)), 138.36.37 (C(2)), 137.40 (C(1’)), 128.97 (C(3’)), $128.11\left(\mathrm{C}\left(2^{\prime}\right)\right)$, 126.52 (C(4’)), 125.68 (C(1)), 73.09 (C(3)), 47.66 (C(4)), 43.52 (C(6)), 25.64 (C(7)), $22.25(\mathrm{C}(8)), 13.97\left(\mathrm{H}_{3} \mathrm{C}(1 ")\right), 13.79$ (C(9))

Opt. Rot.: $\quad[\alpha]_{\mathrm{D}}^{24}+1.15\left(\mathrm{c}=1.00, \mathrm{CHCl}_{3}\right)$

SFC: $\quad(R)-14 t_{\mathrm{R}} 2.91 \min (78.0 \%) ;(S)-14 t_{\mathrm{R}} 3.42 \min (22.0 \%)$ (AD column, 125 bar, 2.5 $\mathrm{mL} / \mathrm{min}, 15.0 \% \mathrm{MeOH})$

\section{(+)-(R)-1-Hydroxy-1-(1-napthyl)-3-heptanone (15) [JRH-II-87]}
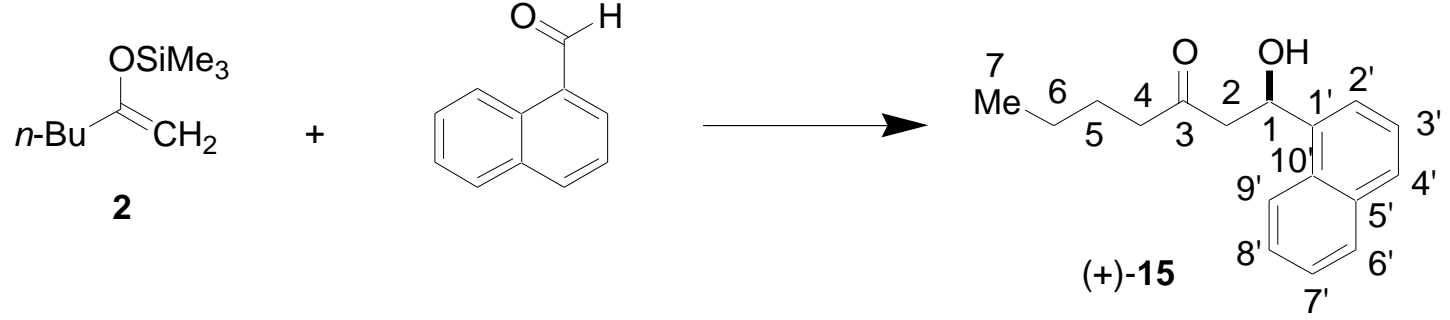

Diisopropylethylamine (18 $\mu \mathrm{L}, 0.1 \mathrm{mmol}, 0.1$ equiv) was added via syringe to a flamedried, 5-mL, schlenk flask under $\mathrm{N}_{2}$ containing a solution of $42 \mathrm{mg}$ (0.05 mmol, 0.05 equiv) of bisphosphoramide $(R, R)-7$ in $\mathrm{CH}_{2} \mathrm{Cl}_{2}(2 \mathrm{~mL})$. To this solution was added $136 \mu \mathrm{L}(1.0 \mathrm{mmol})$ of 1-naphthaldehyde in one portion. To the resulting solution was added $172 \mu \mathrm{L}(1.5 \mathrm{mmol}, 1.5$ 
equiv) of $\mathrm{SiCl}_{4}$ in one portion and the reaction mixture was cooled to $-72{ }^{\circ} \mathrm{C}$ over $15 \mathrm{~min}$. Then, $206 \mathrm{mg}$ (1.2 mmol, 1.2 equiv) of 2 was added dropwise neat over $5 \mathrm{~min}$. The resulting mixture was stirred at $-72{ }^{\circ} \mathrm{C}$ for $10 \mathrm{~h}$ whereupon $3.0 \mathrm{~mL}$ of chilled $\mathrm{CH}_{2} \mathrm{Cl}_{2}$ was added before the cold reaction mixture was poured into a rapidly stirring solution of $1 / 1$ sat. aq. $\mathrm{NaHCO}_{3} /$ sat. aq. $\mathrm{KF}$ $(25 \mathrm{~mL})$ at $0^{\circ} \mathrm{C}$. This biphasic mixture was stirred vigorously for $4 \mathrm{~h}$ after which the aqueous layer was washed with $\mathrm{CH}_{2} \mathrm{Cl}_{2}(3 \times 50 \mathrm{~mL})$. The combined organic extracts were dried over $\mathrm{Na}_{2} \mathrm{SO}_{4}$, filtered and the filtrate was concentrated in vacuo. The residue was purified by column chromatography (silica gel, pentane/Et $2 \mathrm{O}, 4 / 1$ ). The product-containing fractions were combined and the solvent was removed in vacuo to yield $242 \mathrm{mg}(95 \%)$ of (+)-15 as a clear, colorless oil. ${ }^{7 \mathrm{~b}}$ Data for $(+)-\mathbf{1 5}$ :

${ }^{1} \mathrm{H}$ NMR: $\quad\left(500 \mathrm{MHz}, \mathrm{CHCl}_{3}\right)$ $8.00\left(\mathrm{~d}, J=8.3,1 \mathrm{H}, \mathrm{HC}\left(2^{\prime}\right)\right), 7.88$ (d, $\left.J=7.8,1 \mathrm{H}, \mathrm{HC}\left(6^{\prime}\right)\right), 7.79$ (d, $J=8.3,1 \mathrm{H}$, $\left.\mathrm{HC}\left(4^{\prime}\right)\right), 7.70\left(\mathrm{~d}, J=7.1,1 \mathrm{H}, \mathrm{HC}\left(9^{\prime}\right)\right)$, 7.54-7.48 (m, $3 \mathrm{H}, \mathrm{HC}\left(3^{\prime}\right), \mathrm{HC}\left(7^{\prime}\right)$, HC(8’)), 5.96 (dt, $J=8.8,3.1,1 \mathrm{H}, \mathrm{HC}(1)), 3.48$ (d, J = 3.21 H, OH), 2.99 (奋XX, $\left.J_{\mathrm{AB}}=17.8, \mathrm{~J}_{\mathrm{AX}}=9.2,1 \mathrm{H}, \mathrm{H}_{a} \mathrm{C}(2)\right), 2.95\left(\mathrm{ABX}, J_{\mathrm{AB}}=17.8, J_{\mathrm{BX}}=3.0,1 \mathrm{H}\right.$, $\left.\mathrm{H}_{b} \mathrm{C}(2)\right), 2.46\left(\mathrm{t}, J=7.3,2 \mathrm{H}, \mathrm{H}_{2} \mathrm{C}(4)\right), 1.60$ (quint, $J=7.6,2 \mathrm{H}, \mathrm{H}_{2} \mathrm{C}(5)$ ), 1.33 (sext, $\left.J=7.3,2 \mathrm{H}, \mathrm{H}_{2} \mathrm{C}(6)\right), 0.91\left(\mathrm{t}, J=7.3,3 \mathrm{H}, \mathrm{H}_{3} \mathrm{C}(7)\right.$ )

${ }^{13} \mathrm{C} \mathrm{NMR}: \quad\left(126 \mathrm{MHz}, \mathrm{CHCl}_{3}\right)$

211.82 (C(3)), $138.37\left(\mathrm{C}\left(1^{\prime}\right)\right), 133.75$ (C(5’)), $129.86\left(\mathrm{C}\left(10^{\prime}\right)\right), 129.01\left(\mathrm{C}\left(6^{\prime}\right)\right)$, 128.03 (C(4’)), $126.71\left(\mathrm{C}\left(6^{\prime}\right)\right), 125.54\left(\mathrm{C}\left(7^{\prime}\right)\right), 125.52$ (C(3’)), $122.96\left(\mathrm{C}\left(9^{\prime}\right)\right)$, $122.73\left(\mathrm{C}\left(2^{\prime}\right)\right), 66.76$ (C(1)), 50.29 (C(2)), 43.39 (C(4)), $25.63(\mathrm{C}(5)), 22.21$ $(\mathrm{C}(6)), 13.76(\mathrm{C}(7))$

Opt. Rot.: $\quad[\alpha]_{\mathrm{D}}^{24}+44.47(\mathrm{c}=1.30, \mathrm{EtOH})$ $[\alpha]_{\mathrm{D}}^{24}+79.94\left(\mathrm{c}=1.40, \mathrm{CHCl}_{3}\right)$

SFC: $\quad(R)-15 t_{\mathrm{R}} 4.41 \min (96.0 \%) ;(S)-15 t_{\mathrm{R}} 4.86 \min (4.0 \%)$ (AD column, 125 bar, 2.5 $\mathrm{mL} / \mathrm{min}, 15.0 \% \mathrm{MeOH})$ 
(+)-(R)-1-Hydroxy-1-(2-napthyl)-3-heptanone (16) [JRH-II-95]

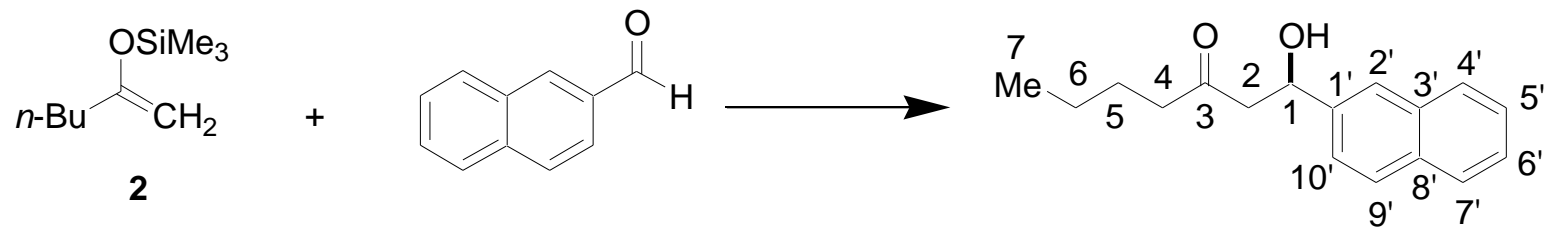

$(+)-16$

Diisopropylethylamine (18 $\mu \mathrm{L}, 0.1 \mathrm{mmol}, 0.1$ equiv) was added via syringe to a flamedried, 5-mL, Schlenk flask under $\mathrm{N}_{2}$ containing a solution of $42 \mathrm{mg}$ (0.05 mmol, 0.05 equiv) of bisphosphoramide $(R, R)-7$ in $\mathrm{CH}_{2} \mathrm{Cl}_{2}(2 \mathrm{~mL})$. To this solution was added $156 \mathrm{mg}(1.0 \mathrm{mmol})$ of 2-naphthaldehyde in one portion. To the resulting solution was added $172 \mu \mathrm{L}(1.5 \mathrm{mmol}, 1.5$ equiv) of $\mathrm{SiCl}_{4}$ in one portion and the reaction mixture was cooled to $-72{ }^{\circ} \mathrm{C}$ over $15 \min$. Then, $206 \mathrm{mg}$ (1.2 mmol, 1.2 equiv) of 2 was added dropwise neat over $5 \mathrm{~min}$. The resulting mixture was stirred at $-72{ }^{\circ} \mathrm{C}$ for $4 \mathrm{~h}$ whereupon $3.0 \mathrm{~mL}$ of chilled $\mathrm{CH}_{2} \mathrm{Cl}_{2}$ was added before the cold reaction mixture was poured into a rapidly stirring solution of $1 / 1$ sat. aq. $\mathrm{NaHCO}_{3} / \mathrm{sat}$ aq. $\mathrm{KF}(25 \mathrm{~mL})$ at $0^{\circ} \mathrm{C}$. This biphasic mixture was stirred vigorously for $4 \mathrm{~h}$ after which the aqueous layer was washed with $\mathrm{CH}_{2} \mathrm{Cl}_{2}(3 \times 50 \mathrm{~mL})$. The combined organic extracts were dried over $\mathrm{Na}_{2} \mathrm{SO}_{4}$, filtered and the filtrate was concentrated in vacuo. The residue was purified by column chromatography (silica gel, pentane/ $\mathrm{Et}_{2} \mathrm{O}, 4 / 1$ ) to give a solid, which was recrystallized from hexanes to give $235 \mathrm{mg}(92 \%)$ of (+)-16 as white needles.

Data for $(+)-\mathbf{1 6}$ :

mp: $\quad 55-56{ }^{\circ} \mathrm{C}$ (hexanes)

${ }^{1} \mathrm{H} \mathrm{NMR}: \quad\left(500 \mathrm{MHz}, \mathrm{CHCl}_{3}\right)$

$7.83(\mathrm{~m}, 4 \mathrm{H}, \mathrm{H}(\operatorname{aryl})), 4.57$ (m, $3 \mathrm{H}, \mathrm{H}(\operatorname{aryl})), 5.33$ (dt, $J=8.3,3.5,1 \mathrm{H}, \mathrm{HC}(1))$,

$3.49(\mathrm{~m}, 1 \mathrm{H}, \mathrm{OH}), 2.91\left(\mathrm{~m}, 2 \mathrm{H}, \mathrm{H}_{2} \mathrm{C}(2)\right), 2.46\left(\mathrm{t}, J=7.4,2 \mathrm{H}, \mathrm{H}_{2} \mathrm{C}(4)\right), 1.58$

(quint, $J=7.6,2 \mathrm{H}, \mathrm{H}_{2} \mathrm{C}(5)$ ), 1.32 (sext, $J=7.5,2 \mathrm{H}, \mathrm{H} 2 \mathrm{C}(6)$ ), 0.90 (t, $J=7.4,3$

$\left.\mathrm{H}, \mathrm{H}_{3} \mathrm{C}(7)\right)$ 
${ }^{13} \mathrm{C} \mathrm{NMR}: \quad\left(126 \mathrm{MHz}, \mathrm{CHCl}_{3}\right)$

$211.66(\mathrm{C}(3)), 140.22\left(\mathrm{C}\left(1^{\prime}\right)\right), 133.27\left(\mathrm{C}\left(3^{\prime}\right)\right), 132.90\left(\mathrm{C}\left(8^{\prime}\right)\right), 128.28\left(\mathrm{C}\left(7^{\prime}\right)\right)$, $127.95\left(\mathrm{C}\left(4^{\prime}\right)\right), 127.64\left(\mathrm{C}\left(10^{\prime}\right)\right), 126.16\left(\mathrm{C}\left(9^{\prime}\right)\right), 125.86\left(\mathrm{C}\left(2^{\prime}\right)\right), 124.30\left(\mathrm{C}\left(5^{\prime}\right)\right)$, 123.72 (C(6')), $70.00(\mathrm{C}(1)), 50.89(\mathrm{C}(2)), 43.39$ (C(4)), $25.57(\mathrm{C}(5)), 22.17$ $(\mathrm{C}(6)), 13.74(\mathrm{C}(7))$

IR: $\quad\left(\mathrm{CHCl}_{3}\right)$

3602 (m), 3504 (m), 3155 (m), 3060 (m), 2960 (m), 2933 (m), 2875 (m), 1793 (m), 1703 (s), 1603 (m), 1468 (m), 1383 (m), 1327 (m), 1269 (m), 1124 (m), 1093 (m)

MS: $\quad(E I, 70 \mathrm{eV})$

257 (11), 256 (M+, 48), 157 (44), 156 (100), 155 (51), 154 (10), 153 (19), 129 (40), 128 (47), 127 (48), 126 (12)

Opt. Rot.: $\quad[\alpha]_{\mathrm{D}}^{24}+31.76(\mathrm{c}=1.00, \mathrm{EtOH})$

TLC: $\quad \mathrm{R}_{f} 0.24$ (hexane/EtOAc, 3/1) [silica gel]

SFC: $\quad(R)-16 t_{\mathrm{R}} 7.86 \min (99.5 \%) ;(S)-16 t_{\mathrm{R}} 8.54 \min (0.5 \%)$ (AD column, $125 \mathrm{bar}, 3.0$ $\mathrm{mL} / \mathrm{min}, 8.0 \% \mathrm{MeOH}$ )

Analysis: $\quad \mathrm{C}_{17} \mathrm{H}_{20} \mathrm{O}_{2}(256.34)$

Calcd: $\quad$ C, $79.65 ; \quad$ H, $7.86 \%$

Found: $\quad \mathrm{C}, 79.56 ; \quad \mathrm{H}, 7.86 \%$ 
(+)-(R)-1-Hydroxy-1-(4-methoxyphenyl)-3-heptanone (17) [JRH-III-16]

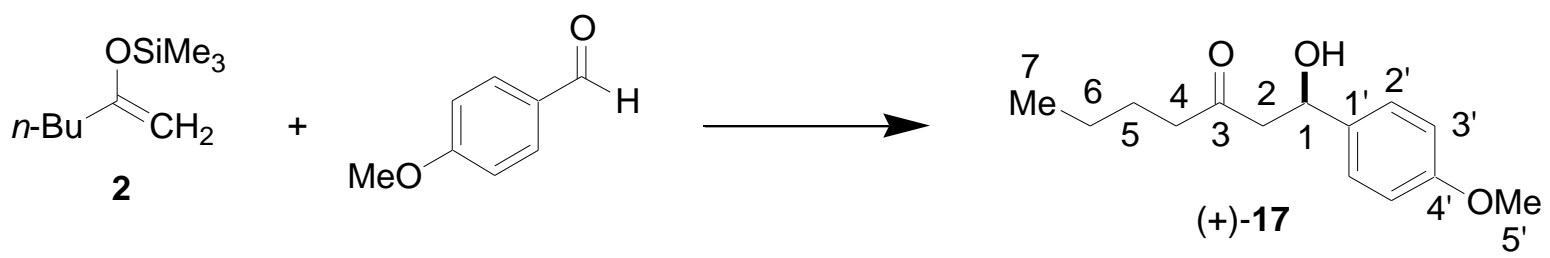

Diisopropylethylamine (18 $\mu \mathrm{L}, 0.1 \mathrm{mmol}, 0.1$ equiv) was added via syringe to a flamedried, 5-mL, Schlenk flask under $\mathrm{N}_{2}$ containing a solution of $42 \mathrm{mg}$ (0.05 mmol, 0.05 equiv) of bis-phosphoramide $(R, R)-7$ in $\mathrm{CH}_{2} \mathrm{Cl}_{2}(2 \mathrm{~mL})$. To this solution was added $122 \mu \mathrm{L}(1.0 \mathrm{mmol})$ of 4-trifluoromethylbenzaldehyde in one portion. To the resulting solution was added $172 \mu \mathrm{L}$ (1.5 mmol, 1.5 equiv) of $\mathrm{SiCl}_{4}$ in one portion and the reaction mixture was cooled to $-72{ }^{\circ} \mathrm{C}$ over 15 min. Then, $206 \mathrm{mg}$ (1.2 mmol, 1.2 equiv) of 2 was added dropwise neat over $5 \mathrm{~min}$. The resulting mixture was stirred at $-72{ }^{\circ} \mathrm{C}$ for $4 \mathrm{~h}$ whereupon $3.0 \mathrm{~mL}$ of chilled $\mathrm{CH}_{2} \mathrm{Cl}_{2}$ was added before the cold reaction mixture was poured into a rapidly stirring solution of $1 / 1$ sat. aq. $\mathrm{NaHCO}_{3} /$ sat. aq. $\mathrm{KF}(25 \mathrm{~mL})$ at $0^{\circ} \mathrm{C}$. This biphasic mixture was stirred vigorously for $1 \mathrm{~h}$ before being filtered through Celite. The phases were then separated and the aqueous layer was washed with $\mathrm{CH}_{2} \mathrm{Cl}_{2}(3 \times 50 \mathrm{~mL})$. The combined organic extracts were dried over $\mathrm{Na}_{2} \mathrm{SO}_{4}$, filtered and the filtrate was concentrated in vacuo. The residue was purified by column chromatography (silica gel, pentane/Et $2 \mathrm{O}, 4 / 1)$ to give $230 \mathrm{mg}(97.8 \%)$ of (+)-17 as a clear, colorless oil.

Data for (+)-17:

${ }^{1}$ H NMR: $\quad\left(500 \mathrm{MHz}, \mathrm{CHCl}_{3}\right)$

7.29-7.27 (m, 2 H, HC(2’)), 6.90-6.87 (m, 2 H, HC(3’)), 5.11 (dd, J = 9.0, 3.2, 1 $\mathrm{H}, \mathrm{HC}(1)), 3.80$ (s, $\left.3 \mathrm{H}, \mathrm{H}_{3} \mathrm{C}\left(5^{\prime}\right)\right), 3.28$ (br s, $\left.1 \mathrm{H}, \mathrm{OH}\right), 2.84\left(\left(\underline{\mathrm{ABX}}, J_{\mathrm{AB}}=17.3\right.\right.$, $\left.J_{\mathrm{AX}}=11.4,1 \mathrm{H}, \mathrm{H}_{a} \mathrm{C}(2)\right), 2.77\left(\mathrm{~A} \underline{\mathrm{BX}}, J_{\mathrm{AB}}=17.3, J_{\mathrm{BX}}=1.3,1 \mathrm{H}, \mathrm{H}_{b} \mathrm{C}(2)\right), 2.43(\mathrm{t}$, $J=7.3,2 \mathrm{H}, \mathrm{H}_{2} \mathrm{C}(4)$ ), 1.56 (quint, $J=7.3,2 \mathrm{H}, \mathrm{H}_{2} \mathrm{C}(5)$ ), 1.31 (sext, $J=7.5,2 \mathrm{H}$, $\left.\mathrm{H}_{2} \mathrm{C}(6)\right), 0.90\left(\mathrm{t}, J=7.3,3 \mathrm{H}, \mathrm{H}_{3} \mathrm{C}(7)\right)$ 
${ }^{13}$ C NMR: $\quad\left(126 \mathrm{MHz}, \mathrm{CHCl}_{3}\right)$

$211.80(\mathrm{C}(3)), 159.12\left(\mathrm{C}\left(4^{\prime}\right)\right), 135.04\left(\mathrm{C}\left(1^{\prime}\right)\right), 126.92\left(\mathrm{C}\left(2^{\prime}\right)\right), 113.90\left(\mathrm{C}\left(3^{\prime}\right)\right)$, $69.59(\mathrm{C}(1)), 55.28\left(\mathrm{C}\left(5^{\prime}\right)\right), 50.95(\mathrm{C}(2)), 43.41(\mathrm{C}(4)), 25.61(\mathrm{C}(5)), 22.22$ $(\mathrm{C}(6)), 13.78(\mathrm{C}(7))$

IR: (neat) 3458 (s), 2999 (m), 2958 (s), 2933 (s), 2873 (s), 2837 (m), 2060 (w), 1890 (w), 1709 (s), 1612 (s), 1587 (m), 1514 (s), 1464 (s), 1406 (s), 1381 (s), 1302 (s), 1176 (s), $1128(\mathrm{~m}), 1078(\mathrm{~m}), 1036(\mathrm{~s}), 833$ (s)

MS: $\quad\left(\mathrm{CI}, \mathrm{CH}_{4}\right)$

$236(\mathrm{M}+, 15), 220$ (17), 219 (100), 137 (52), 136 (6), 135 (10), 85 (25)

Opt. Rot.: $\quad[\alpha]_{\mathrm{D}}^{24}+27.47(\mathrm{c}=1.20, \mathrm{EtOH})$

TLC: $\quad \mathrm{R}_{f} 0.22$ (hexane/EtOAc, 2/1) [silica gel]

SFC: $\quad(R)-17 t_{\mathrm{R}} 4.21 \min (99.5 \%) ;(S)-17 t_{\mathrm{R}} 4.83 \min (0.5 \%)$ (AS column, 125 bar, 3.0 $\mathrm{mL} / \mathrm{min}, 4.0 \% \mathrm{MeOH})$

Analysis: $\quad \mathrm{C}_{14} \mathrm{H}_{20} \mathrm{O}_{3}(236.31)$

Calcd: $\quad$ C, $71.16 ; \quad \mathrm{H}, 8.53 \%$

Found: $\quad$ C, $70.98 ; \quad H, 8.53 \%$

\section{(+)-(R)-1-Hydroxy-1-(4-trifluoromethylphenyl)-3-heptanone (18) [JRH-III-07]}

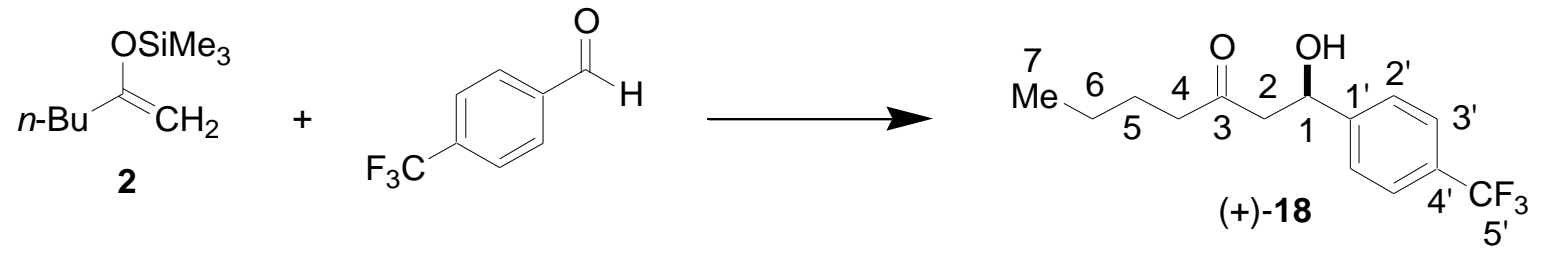

Diisopropylethylamine (18 $\mu \mathrm{L}, 0.1 \mathrm{mmol}, 0.1$ equiv) was added via syringe to a flamedried, 5-mL, Schlenk flask under $\mathrm{N}_{2}$ containing a solution of $42 \mathrm{mg}$ (0.05 mmol, 0.05 equiv) of bisphosphoramide $(R, R)-7$ in $\mathrm{CH}_{2} \mathrm{Cl}_{2}(2 \mathrm{~mL})$. To this solution was added $137 \mu \mathrm{L}(1.0 \mathrm{mmol})$ of 4-trifluoromethylbenzaldehyde in one portion. To the resulting solution was added $172 \mu \mathrm{L}(1.5$ 
mmol, 1.5 equiv) of $\mathrm{SiCl}_{4}$ in one portion and the reaction mixture was cooled to $-72{ }^{\circ} \mathrm{C}$ over 15 min. Then, $206 \mathrm{mg}$ (1.2 mmol, 1.2 equiv) of 2 was added dropwise neat over $5 \mathrm{~min}$. The resulting mixture was stirred at $-72{ }^{\circ} \mathrm{C}$ for $4 \mathrm{~h}$ whereupon $3.0 \mathrm{~mL}$ of chilled $\mathrm{CH}_{2} \mathrm{Cl}_{2}$ was added before the cold reaction mixture was poured into a rapidly stirring solution of $1 / 1$ sat. aq. $\mathrm{NaHCO}_{3} /$ sat. aq. $\mathrm{KF}(25 \mathrm{~mL})$ at $0^{\circ} \mathrm{C}$. This biphasic mixture was stirred vigorously for $4 \mathrm{~h}$ after which the aqueous layer was washed with $\mathrm{CH}_{2} \mathrm{Cl}_{2}(3 \times 50 \mathrm{~mL})$. The combined organic extracts were dried over $\mathrm{Na}_{2} \mathrm{SO}_{4}$, filtered and the filtrate was concentrated in vacuo. The residue was purified by column chromatography ( distilled (bulb-to-bulb) to give $264 \mathrm{mg}(96 \%)$ of (+)-18 as a clear, colorless oil.

$\underline{\text { Data for }(+)-\mathbf{1 8}}$

bp: $\quad 210{ }^{\circ} \mathrm{C}(0.2 \mathrm{mmHg}, \mathrm{ABT})$

${ }^{1} \mathrm{H} \mathrm{NMR}: \quad\left(500 \mathrm{MHz}, \mathrm{CHCl}_{3}\right)$

$7.61\left(\mathrm{~d}, J=8.3,2 \mathrm{H}, \mathrm{HC}\left(2^{\prime}\right)\right), 7.48\left(\mathrm{~d}, \mathrm{~J}=8.1,2 \mathrm{H}, \mathrm{HC}\left(3^{\prime}\right)\right), 5.21(\mathrm{t}, J=6.2,1 \mathrm{H}$, $\mathrm{HC}(1)), 3.57$ (br s, $1 \mathrm{H}, \mathrm{OH}), 2.81$ (d, J=6.1, $\left.2 \mathrm{H}, \mathrm{H}_{2} \mathrm{C}(2)\right), 2.44$ (t, J = 7.4, $2 \mathrm{H}$, $\mathrm{H}_{2} \mathrm{C}(4)$ ), 1.57 (quint, $J=7.3,2 \mathrm{H}, \mathrm{H}_{2} \mathrm{C}(5)$ ), 1.31 (sext, $J=7.4,2 \mathrm{H}, \mathrm{H}_{2} \mathrm{C}(6)$ ), 0.90 $\left(\mathrm{t}, J=7.3,3 \mathrm{H}, \mathrm{H}_{3} \mathrm{C}(7)\right)$

${ }^{13} \mathrm{C} \mathrm{NMR}: \quad\left(126 \mathrm{MHz}, \mathrm{CHCl}_{3}\right)$

$211.46(\mathrm{C}(3)), 146.78\left(\mathrm{C}\left(1^{\prime}\right)\right), 129.67\left(\mathrm{q}, \mathrm{J}_{\mathrm{CF}}=32, \mathrm{C}\left(4^{\prime}\right)\right), 125.91\left(\mathrm{C}\left(2^{\prime}\right)\right), 125.46$ $\left(\mathrm{q}, \mathrm{J}_{\mathrm{CF}}=4, \mathrm{C}\left(3^{\prime}\right)\right), 124.10\left(\mathrm{q}, \mathrm{J}=272, \mathrm{C}\left(5^{\prime}\right)\right), 69.30(\mathrm{C}(1)), 50.70(\mathrm{C}(2)), 43.36$ (C(4)), $25.58(\mathrm{C}(5)), 22.19(\mathrm{C}(6)), 13.74(\mathrm{C}(7))$

${ }^{19}$ F NMR: $\quad\left(376 \mathrm{MHz}, \mathrm{CHCl}_{3} \mathrm{w} / \mathrm{C}_{6} \mathrm{~F}_{6}\right)$ $-62.716$

IR: (neat) 3444 (m), 2962 (m), 2935 (m), $2875(\mathrm{~m}), 1711(\mathrm{~s}), 1620(\mathrm{~m}), 1468(\mathrm{~m}), 1412(\mathrm{~m})$, 1327 (s), 1165 (s), 1126 (s), 1068 (s), 1018 (m), 839 (m)

MS: $\quad\left(\mathrm{CI}, \mathrm{CH}_{4}\right)$ $274(\mathrm{M}+, 6), 256$ (6), 257 (9), 255 (20), 217 (7), 175 (7), 101 (9), 85 (100), 59 (6) 
Opt. Rot.: $\quad[\alpha]_{\mathrm{D}}^{24}+29.07(\mathrm{c}=1.20, \mathrm{EtOH})$

TLC: $\quad \mathrm{R}_{f} 0.26$ (hexane/EtOAc, 3/1) [silica gel]

SFC: $\quad(R)-9 t_{\mathrm{R}} 7.76 \min (>99.5 \%) ;(S)-9 t_{\mathrm{R}} 8.70 \mathrm{~min}(<0.5 \%)$ (Welko column, 125 bar, $2.5 \mathrm{~mL} / \mathrm{min}, 1.0 \% \mathrm{MeOH})$

Analysis: $\quad \mathrm{C}_{14} \mathrm{H}_{17} \mathrm{~F}_{3} \mathrm{O}_{2}(274.28)$

Calcd: $\quad$ C, $61.31 ; \quad \mathrm{H}, 6.25 \%$

Found: $\quad$ C, 61.41; $\quad$ H, 6.43\%

(+)-(R)-1-Hydroxy-1-fural-3-heptanone (19) [JRH-III-17]

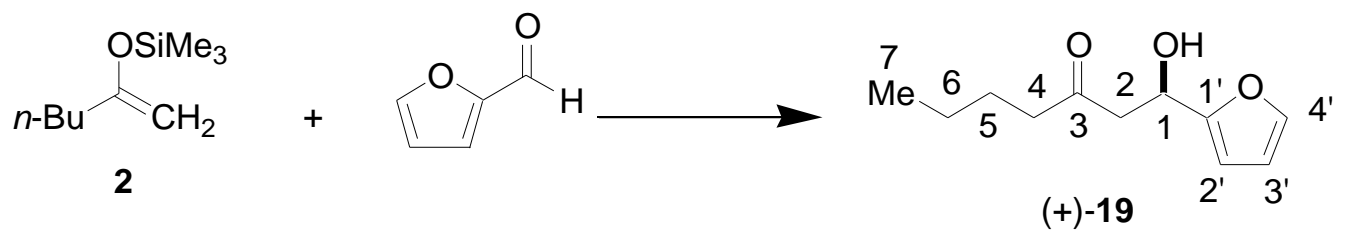

Diisopropylethylamine (18 $\mu \mathrm{L}, 0.1 \mathrm{mmol}, 0.1$ equiv) was added via syringe to a flamedried, 5-mL, Schlenk flask under $\mathrm{N}_{2}$ containing a solution of $42 \mathrm{mg}$ (0.05 mmol, 0.05 equiv) of bis-phosphoramide $(R, R)-7$ in $\mathrm{CH}_{2} \mathrm{Cl}_{2}(2 \mathrm{~mL})$. To this solution was added $82 \mu \mathrm{L}(1.0 \mathrm{mmol})$ of 2-furaldehyde in one portion. To the resulting solution was added $172 \mu \mathrm{L}$ (1.5 mmol, 1.5 equiv) of $\mathrm{SiCl}_{4}$ in one portion and the reaction mixture was cooled to $-72{ }^{\circ} \mathrm{C}$ over $15 \mathrm{~min}$. Then, 206 $\mathrm{mg}$ (1.2 mmol, 1.2 equiv) of 2 was added dropwise neat over $5 \mathrm{~min}$. The resulting mixture was stirred at $-72{ }^{\circ} \mathrm{C}$ for $6 \mathrm{~h}$ whereupon $3.0 \mathrm{~mL}$ of chilled $\mathrm{CH}_{2} \mathrm{Cl}_{2}$ was added before the cold reaction mixture was poured into a rapidly stirring solution of $1 / 1$ sat. aq. $\mathrm{NaHCO}_{3} /$ sat. aq. $\mathrm{KF}(25 \mathrm{~mL})$ at $0^{\circ} \mathrm{C}$. This biphasic mixture was stirred vigorously for $1 \mathrm{~h}$ before being filtered through Celite. The phases were then separated and the aqueous layer was washed with $\mathrm{CH}_{2} \mathrm{Cl}_{2}(3 \times 50 \mathrm{~mL})$. The combined organic extracts were dried over $\mathrm{Na}_{2} \mathrm{SO}_{4}$, filtered and the filtrate was concentrated in vacuo. The residue was purified by column chromatography (silica gel, pentane/Et ${ }_{2} \mathrm{O}, 4 / 1$ ) to give $173 \mathrm{mg}(88 \%)$ of (+)-19 as a clear, colorless oil 


\section{Data for (+)-19:}

${ }^{1} \mathrm{H}$ NMR: $\quad\left(500 \mathrm{MHz}, \mathrm{CHCl}_{3}\right)$

7.36 (m, 1 H, HC(4')), 6.33 (m, 1 H, HC(3')), 6.26 (m, 1 H, HC(2')), 5.17 (dd, $J$ $=9.0,3.2,1 \mathrm{H}, \mathrm{HC}(1)), 3.32($ br s, $1 \mathrm{H}, \mathrm{OH}), 3.03\left(\left(\underline{\mathrm{ABX}}, J_{\mathrm{AB}}=17.6, \mathrm{~J}_{\mathrm{AX}}=9.9,1\right.\right.$ $\left.\mathrm{H}, \mathrm{H}_{a} \mathrm{C}(2)\right), 2.90\left(\mathrm{ABX}, J_{\mathrm{AB}}=17.6, J_{\mathrm{BX}}=2.1,1 \mathrm{H}, \mathrm{H}_{b} \mathrm{C}(2)\right), 2.43(\mathrm{t}, J=7.3,2 \mathrm{H}$, $\mathrm{H}_{2} \mathrm{C}(4)$ ), 1.58 (quint, $J=7.3,2 \mathrm{H}, \mathrm{H}_{2} \mathrm{C}(5)$ ), 1.32 (sext, $J=7.3,2 \mathrm{H}, \mathrm{H}_{2} \mathrm{C}(6)$ ), 0.91 (t, $J=7.3,3 \mathrm{H}, \mathrm{H}_{3} \mathrm{C}(7)$ )

${ }^{13}$ C NMR: $\quad\left(126 \mathrm{MHz}, \mathrm{CHCl}_{3}\right)$

$211.04(\mathrm{C}(3)), 155.03\left(\mathrm{C}\left(1^{\prime}\right)\right), 142.05\left(\mathrm{C}\left(4^{\prime}\right)\right), 110.24\left(\mathrm{C}\left(3^{\prime}\right)\right), 106.20\left(\mathrm{C}\left(2^{\prime}\right)\right)$, $63.83(\mathrm{C}(1)), 47.04(\mathrm{C}(2)), 43.28(\mathrm{C}(4)), 25.57(\mathrm{C}(5)), 22.17(\mathrm{C}(6)), 13.74(\mathrm{C}(7))$

IR: (neat)

3431 (s), 3149 (m), 3120 (m), 2958 (s), 2933 (s), 2873 (s), 1711 (s), 1600 (m), 1504 (m), 1465 (m), 1408 (s), 1379 (s), 1269 (m), 1217 (m), 1147 (s), 1070 (s), $1012(\mathrm{~s})$

MS: $\quad\left(\mathrm{CI}, \mathrm{CH}_{4}\right)$

$196(\mathrm{M}+, 18), 180$ (13), 179 (100), 139 (10), 97 (9), 85 (59)

Opt. Rot.: $\quad[\alpha]_{\mathrm{D}}^{24}+36.27(\mathrm{c}=1.00$, EtOH $)$

TLC: $\quad \mathrm{R}_{f} 0.29$ (hexane/EtOAc, 2/1) [silica gel]

SFC: $\quad(R)-19 t_{\mathrm{R}} 3.85 \mathrm{~min}(95.0 \%) ;(S)-\mathbf{1 9} t_{\mathrm{R}} 4.20 \mathrm{~min}(5.0 \%)$ (OD column, $125 \mathrm{bar}, 3.0$ $\mathrm{mL} / \mathrm{min}, 2.5 \% \mathrm{MeOH}$ )

Analysis: $\quad \mathrm{C}_{11} \mathrm{H}_{16} \mathrm{O}_{3}(196.24)$

Calcd: $\quad$ C, $67.32 ; \quad H, 8.22 \%$

Found: $\quad \mathrm{C}, 67.17 ; \quad \mathrm{H}, 8.28 \%$ 
(+)-(R)-1-Hydroxy-1-thiophene-3-heptanone (20) [JRH-III-17]

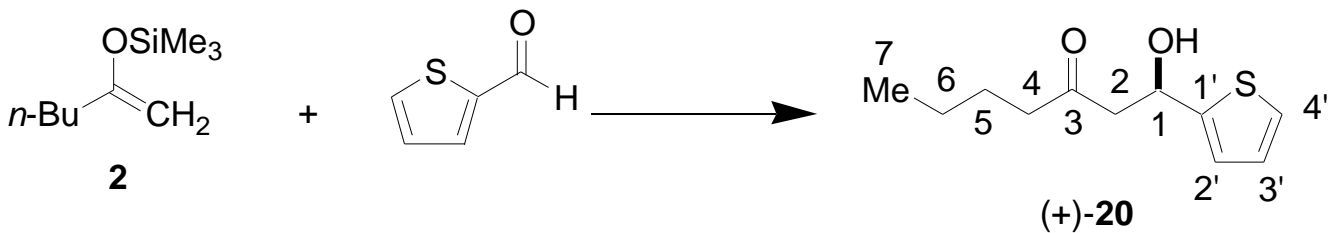

Diisopropylethylamine (18 $\mu \mathrm{L}, 0.1 \mathrm{mmol}, 0.1$ equiv) was added via syringe to a flamedried, 5-mL, Schlenk flask under $\mathrm{N}_{2}$ containing a solution of $42 \mathrm{mg}$ (0.05 mmol, 0.05 equiv) of bisphosphoramide $(R, R)-7$ in $\mathrm{CH}_{2} \mathrm{Cl}_{2}(2 \mathrm{~mL})$. To this solution was added $94 \mu \mathrm{L}$ (1.0 mmol) of 2thiophenecarboxaldehyde in one portion. To the resulting solution was added $172 \mu \mathrm{L}$ (1.5 mmol, 1.5 equiv) of $\mathrm{SiCl}_{4}$ in one portion and the reaction mixture was cooled to $-72{ }^{\circ} \mathrm{C}$ over $15 \mathrm{~min}$. Then, $206 \mathrm{mg}$ (1.2 mmol, 1.2 equiv) of 2 was added dropwise neat over $5 \mathrm{~min}$. The resulting mixture was stirred at $-72{ }^{\circ} \mathrm{C}$ for $6 \mathrm{~h}$ whereupon $3.0 \mathrm{~mL}$ of chilled $\mathrm{CH}_{2} \mathrm{Cl}_{2}$ was added before the cold reaction mixture was poured into a rapidly stirring solution of $1 / 1$ sat. aq. $\mathrm{NaHCO}_{3} /$ sat. aq. $\mathrm{KF}(25 \mathrm{~mL})$ at $0^{\circ} \mathrm{C}$. This biphasic mixture was stirred vigorously for $1 \mathrm{~h}$ before being filtered through Celite. The phases were then separated and the aqueous layer was washed with $\mathrm{CH}_{2} \mathrm{Cl}_{2}$ ( $3 \times 50 \mathrm{~mL}$ ). The combined organic extracts were dried over $\mathrm{Na}_{2} \mathrm{SO}_{4}$, filtered and the filtrate was concentrated in vacuo. The residue was purified by column chromatography (Silica gel, pentane/Et $2 \mathrm{O}, 4 / 1)$ to give $167 \mathrm{mg}(79 \%)$ of (+)-20 as a clear, colorless oil.

\section{Data for $(+)-20$ :}

${ }^{1}$ H NMR: $\quad\left(500 \mathrm{MHz}, \mathrm{CHCl}_{3}\right)$

7.25 (m, 1 H, HC(4')), 6.97 (m, 2 H, HC(3'), $\left.\mathrm{HC}\left(2^{\prime}\right)\right)$ ), 5.41 (dt, J = 8.5, 3.7, 1 H, $\mathrm{HC}(1)), 3.32(\mathrm{~d}, J=3.7,1 \mathrm{H}, \mathrm{OH}), 2.98\left(\left(\underline{\mathrm{ABX}}, J_{\mathrm{AB}}=17.3, \mathrm{~J}_{\mathrm{AX}}=9.2,1 \mathrm{H}\right.\right.$, $\left.\mathrm{H}_{a} \mathrm{C}(2)\right), 2.93\left(\mathrm{ABX}, J_{\mathrm{AB}}=17.3, J_{\mathrm{BX}}=3.1,1 \mathrm{H}, \mathrm{H}_{b} \mathrm{C}(2)\right), 2.46(\mathrm{t}, J=7.3,2 \mathrm{H}$, $\mathrm{H}_{2} \mathrm{C}(4)$ ), 1.58 (quint, $J=7.4,2 \mathrm{H}, \mathrm{H}_{2} \mathrm{C}(5)$ ), 1.32 (sext, $J=7.4,2 \mathrm{H}, \mathrm{H}_{2} \mathrm{C}(6)$ ), 0.91 $\left(\mathrm{t}, J=7.3,3 \mathrm{H}, \mathrm{H}_{3} \mathrm{C}(7)\right)$ 
${ }^{13} \mathrm{C} \mathrm{NMR}: \quad\left(126 \mathrm{MHz}, \mathrm{CHCl}_{3}\right)$

$211.07(\mathrm{C}(3)), 146.61\left(\mathrm{C}\left(1^{\prime}\right)\right), 126.60\left(\mathrm{C}\left(3^{\prime}\right)\right), 124.59\left(\mathrm{C}\left(4^{\prime}\right)\right), 123.42\left(\mathrm{C}\left(2^{\prime}\right)\right)$, $66.15(\mathrm{C}(1)), 50.70(\mathrm{C}(2)), 43.29(\mathrm{C}(4)), 25.48(\mathrm{C}(5)), 22.13(\mathrm{C}(6)), 13.72(\mathrm{C}(7))$

$\underline{\text { IR: }} \quad$ (neat)

3440 (m), 3107 (m), 3072 (w), 2958 (s), 2933 (s), 2872 (m), 2360 (w), 2341 (w) 1709 (s), 1464 (m), 1441 (m), 1404 (m), 1381 (s), 1309 (m), 1269 (m), 1227 (m), $1128(\mathrm{~m}), 1078(\mathrm{~m}), 1038(\mathrm{~s}), 852(\mathrm{~m}), 833(\mathrm{~m}), 700(\mathrm{~s})$

MS: $\quad(E I, 70 \mathrm{eV})$

212 (M+, 70), 155 (26), 127 (28), 113 (100), 112 (34), 111 (28), 110 (14), 109 (19), 85 (51), 58 (46), 57 (34)

Opt. Rot.: $\quad[\alpha]_{\mathrm{D}}^{24}+15.96(\mathrm{c}=1.00$, EtOH $)$

TLC: $\quad \mathrm{R}_{f} 0.36$ (hexane/EtOAc, 2/1) [silica gel]

SFC: $\quad(R)-20 t_{\mathrm{R}} 6.32 \min (90.0 \%) ;(S)-20 t_{\mathrm{R}} 6.78 \min (10.0 \%)$ (OD column, $125 \mathrm{bar}$, $3.5 \mathrm{~mL} / \mathrm{min}, 3.0 \% \mathrm{MeOH})$

Analysis: $\quad \mathrm{C}_{11} \mathrm{H}_{16} \mathrm{O}_{2} \mathrm{~S}(212.31)$

Calcd: $\quad$ C, $62.23 ; \quad$ H, $7.60 \%$

Found: $\quad \mathrm{C}, 62.37 ; \quad \mathrm{H}, 7.56 \%$

\section{References}

(1) Corey, E. J.; Gross, A. W. Tetrahedron Lett. 1994, 25, 495.

(2) Myles, D. C.; Bigham, M. H. Org. Syn. 1992, 72, 331.

(3) Denmark, S. E.; Wynn, T. J. Am. Chem. Soc. 2001, 123, 6199.

(4) Denmark, S. E.; Stavenger, R. A. J. Am. Chem. Soc. 2000, 122, 8837. 